\title{
REBA NAM PROMJENA Ideje rasta i razvoja u doba krize fosilne energije i kapitalizma
}

\author{
Mladen Domazet \\ Grupa 22, Zagreb
}

Cilj ovoga rada jest postaviti temelje za holističko poimanje ekonomskih nada i geofizičkih pokretača u pozadini zelene ekonomije i od-rasta (eng. degrowth) te potaknuti druge da ih iskopaju. Rad ponajprije nastoji oblikovati okvir koji bi ujedinio upozorenja o slomu globalne civilizacije, njegovim fizičkim i povijesnim pokretačima i iskustvenim otjelotvorenjima. Baveći se idejom da globalnoj civilizaciji kakvu poznajemo prijeti slom ljudskih društava i praksi koje ih održavaju, rad donosi pregled stavova znanstvenika iz područja znanosti o okolišu, biologije, povijesti, ljevičarske društvene teorije i ekonomije. ${ }^{1}$ Iako postoje historijski narativi koji pobuđuju nadu u tehnologiju kao sredstvo prevladavanja ovoga problema, u ovome ću tekstu nastojati pokazati da se ta vrsta rizika temelji na ontološkoj zabuni oko temeljnih elemenata suvremenog razvojnog uspjeha. Rad pojašnjava da ključni model za ublažavanje sloma ne počiva na malim promjenama u životnom stilu koje, pak, ovise o tehnološkom nadilaženju fizičkih ograničenja, već na ozbiljnom društvenom restrukturiranju koje bi zamijenilo tehnološko rješenje koje nedostaje. No da bi takvo što postalo demokratski prihvatljivo, društva moraju iznova otvoriti pitanje indikatora i definicija komponenata blagostanja; na čovječanstvu je, pak, da napusti nadu u čudo zelene ekonomije i umjesto toga propita u čemu leži njegova održivost.

Ključne riječi: razvoj, politička ekonomija, klimatske promjene, priroda, civilizacija, kapitalizam

Protekle godine bilježe odlučan pokušaj ponovnog ispisivanja povijesti sa stajališta ekonomije. Međutim, takav pristup ne zadire dovoljno duboko. Misli i društveni život čovjeka izgrađeni su na njegovom ekonomskom životu, koji pak počiva na biološkim temeljima. Klima i geologija među sobom odlučuju gdje će biti nalazišta sirovina potrebnih ljudskoj industriji, gdje će biti moguće pokrenuti proizvodnju; o klimi, pak, ovisi gdje će se osloboditi izvori ljudske energije. Promjene klime uzrokuju migracije, a migracije dovode ne samo do ratova, već i do plodnog miješanja ideja nužnog za ubrzan napredak civilizacije.

(Huxley 1953: 61)

[Svoje nadahnuće kritički racionalizam duguje] cjelokupnoj ambiciji Prosvjetiteljstva da stvori povijesno utemeljenu ljudsku znanost koja će jednoga dana dovesti do stvaranja univerzalne civilizacije koja će sve pojedince učiniti neovisnima, autonomnima, oslobođenima i odozgo i odozdo, sposobnima spoznati same sebe, koji za opstanak ovise isključivo jedni o drugima. [...] Velik dio postignuća suvremene civilizacije očito dugujemo brojnim faktorima, od uvećanja znanja na polju medicine, preko informacijskih tehnologija, do bitno uznapredovalih transportnih sredstava; iako predstavljaju neizravno naslijeđe Prosvjetiteljstva i revolucija u znanosti i tehnologiji koje mu i prethode i slijede ga, spomenuti faktori nemaju neposrednu ili izravnu vezu s njegovim idealima. No naša sposobnost da vlastito poimanje svijeta smjestimo u kontekst nečega što je veće od našeg vlastitog malog komadića zemlje, naše vlastite kulture, obitelji ili religije, očito ima.

(Pagden 2013: 315, 350-351)

${ }^{1}$ Više o djelovanju Grupe 22 pogledati na: http://www.grupa22.hr/pocetna/about-us/. 


\section{Uvod}

Iznalaženje vlastitog glasa u tekstu ove vrste nije samo problem akademske apstraktnosti, već i dijagramska ilustracija prirode prepreka s kojima su suočene analiza i strategije posvećene problemu sloma globalne civilizacije uslijed prekoračivanja granica rasta. I dok je istraživanje i međusobno povezivanje spomenutih tema nerijetko osamljenički pothvat, uglavnom uslijed nedostatka službene discipline unutar koje bi se mogla formulirati diskurzivna poigravanja riječima i pronaći zajednica, analiza uzroka i istraživanje strategija oslabljivanja i prilagodbe nužno se tiče "nas" u "razvijenim" društvima, pa i čitavoj ljudskoj populaciji. Veličanstvo "nas” nužno je obilježeno unutarnjim podjelama na one koji raspravljaju, one koji zagađuju, one koji imaju koristi, one koji pate, one koji će patiti, one koji ovo čitaju itd. Svemu tome dodajte sloj promjenjivih vremenskih raspona, od jedinica vremena geoloških sila do raspona pojedinačnih života u odnosu na koje analize i strategije dobivaju značenje.

Da bismo objasnili zašto bi ovo moglo biti posebno doba za čitavu ljudsku populaciju i kulturno zdanje koje je nagomilala, moramo sagledati širu razinu geološke i biološke evolucije i povijesti razvoja, kao i svakodnevnu razinu političkih i ekonomskih napora u životima autora i čitatelja (mene i vas). Ako smatrate da se unutar istoga teksta ništa značajno ne može reći o "čaju” u smislu napitka koji sam jutros popio i robe važne za predindustrijsku trgovinu, nemojte čitati dalje. Jer ovo je tekst koji sebi postavlja upravo takav zadatak: pokazati da i pojedinačno iskustvo i veliki povijesni narativi tvore važnu smislenu cjelinu, sve u svrhu boljeg razumijevanja naše zajedničke budućnosti (i opet, moje i vaše). Ovaj odulji uvod za cilj ima upozoriti na ograničenja jezika, tradicionalno raspodijeljenog među pojedinačnim disciplinama, naročito u akademskom svijetu, koja otežavaju raspravu o stvarnoj i neposrednoj opasnosti. Oslanjajući se na optimističnu nadu u jezičnu prilagodljivost i postizanje razumijevanja među ljudima, istovremeno odbacuje simplicističku nadu u "ozelenjavanje" ekonomskog rasta i "tehnološka rješenja” za fizička ograničenja kapitalističkog modela rasta. Ako još uvijek čitate, znači da ste razumjeli sve što je dosad rečeno; i tako dalje...

U tom duhu ostatak teksta ponudit će upozorenja o kombiniranim društvenim i prirodnim pokretačima sloma proizvodnje dobrobiti kroz medij civilizacije (zajedničko dobro čovječanstva u cjelini), te pregled struktura unutar razvojnog procesa komplementarnih civilizaciji i neutemeljenih obećanja o tehnološkom nadilaženju fizičkih ograničenja i neograničenom rastu bez posljedica. Razlog ovoj taštoj ambiciji jest činjenica da me transdisciplinarni pregled uvjerio da opseg i "opakost” problema iziskuju da se ambicioznim pokušajima rješenja dade prednost nad prokušanim alatima raznih akademskih i tehnoloških disciplina koje razdvajaju pojedinačna i kolektivna iskustva, smanjujući ih na razine kojima je lakše baratati. Također, bez daljnjeg propitkivanja, ovaj tekst pišem iz pozicije da civilizaciju vrijedi sačuvati. Polazeći od toga, nastojat ću pokazati: (a) da nam je potrebna nova vrsta organizacije znanja koja će omogućiti tumačenje složenosti različitih omjera pokretača sloma, (b) da je potrebno definirati globalni subjekt ("mi") tih tumačenja, i (c) da valja ozbiljno porazmisliti o konceptu sloma kao posljedici, mogućnosti i budućnosti koju treba izbjegavati na svakom koraku.

\section{Razvoj, napredak, povijest i nade ljudskih bića}

Dugovječna uzrečica “Živimo u izvanrednim vremenima” uglavnom se koristi za izricanje zabrinutosti zbog društvenih mijena, golemih i dramatičnih događaja ili izazova s kojima je 
suočena svakodnevna egzistencija. Iako možda zvuči kao izvikivanje riječi "Vuk!” u trenutku kada (globalno) selo više ne obraća pažnju, spomenuta uzrečica ovoga puta zaista znači upravo ono što izriče. U prvom redu, "Mi” se odnosi na cjelokupno čovječanstvo koje danas postoji, svih sedam milijardi, što je najveći broj ljudi koji istovremeno preživljavaju na Zemljinim resursima u povijesti. No, što je još važnije, "mi” se odnosi na omanju skupinu građana u samo 47 od nešto manje od 200 zemalja s vrlo visokim Indeksom ljudskog razvoja (eng. Human Development Index, skrać. HDI) (UNDP 2013). U tom kontekstu, "mi" (s malim početnim slovom) obuhvaća manje od petine ljudske populacije, stanovništvo zemalja koje su odgovorne za približno polovicu ukupnog godišnjeg zagađenja stakleničkim plinovima i ekonomske aktivnosti, i kojima pripada većina vojne i političke moći (UNDP 2013).

Istraživanje drugih nejednakosti na planeti, između i unutar pojedinih zemalja, otkrilo bi još više zapanjujuće omjere bogatstva, hrane, zaštite od meteoroloških prilika i slično. Većina tih podataka dobro poznati su memi koji kruže internetom i drugim medijima, prikazani u umjetničkim djelima, ${ }^{2}$ itd. Ono što je naročito zanimljivo u kontekstu ove rasprave jest činjenica da je, gledano iz povijesne perspektive, usporedo s dramatičnim porastom nadzora nad materijalima i pretvorbama energije na razini cjelokupne ljudske vrste, rasla i nejednakost u pristupu i kontroli tih istih materijala i pretvorbi energije unutar vrste. A ipak, sami sebe i dalje vidimo kao dio iste potencijalne, ako ne i stvarne, zajednice. Ovo nije samo ideološka dimna zavjesa: gotovo svi ljudi koji danas žive ne samo da (iz perspektive biologije) dijele isti genetski materijal, već su i dio jezične zajednice, u smislu Wittgensteinovih (1967) jezičnih igara koje možemo igrati jedni s drugima. Bez obzira na visok stupanj srodnosti koju neki ljudi osjećaju prema svojim kućnim ljubimcima, postoje određeni kolektivni pothvati u koje se čovjek upušta samo s drugim voljnim ljudskim bićima, ne i pripadnicima drugih vrsta. No većini ljudi tu očitu činjenicu ionako nije potrebno posebno isticati: ona je dio pretpostavljenog moralnog kodeksa većine. Ovdje je ipak ponavljamo za slučaj da netko, gledajući iz posebne povijesne pozicije, dođe do zaključka da smo dosegli evolucijsku fazu u kojoj su oni koji imaju na neki način fundamentalno različiti i otuđeni od onih koji nemaju. Nisu: i dalje žive na istom planetu i crpe iste oskudne resurse. Oni samo, iz određenih povijesnih i kulturnih razloga, uzimaju mnogo, mnogo veći dio tih resursa nego ikada prije.

Prije svega, valja priznati da su, s obzirom na broj ljudi na planeti, vremena u kojima živimo doista izvanredna. No budući da spomenuti broj posljednjih stoljeća eksponencijalno raste, i to gladima, epidemijama, ratovima i geofizičkim kataklizmama usprkos, izvanredna su (u nešto manjoj mjeri nego danas) već barem sto pedeset godina. Postoji nešto drugo što ih čini zaista izvanrednim. To je drugi poseban uvjet. Paul Crutzen iskovao je termin "antropocen" ${ }^{3}$ kao naziv za novu geološku epohu u životu planeta uzrokovanu ljudskom djelatnošću (za pregled, vidi Zalasiewicz, Crutzen i Steffen 2012). Naziv “antropocen” sugerira da živimo u izvanrednom dobu u kojem naša vrsta, naša društva i kulture djeluju snagom geofizičke sile (Archer 2010; Sager 2011). Geofizičke sile uglavnom uključuju fizičke procese koji uzrokuju pomicanje tektonskih ploča, snažne erupcije vulkana koje mijenjaju koncentraciju različitih sastojaka u zraku, vodi i tlu, ili udare izvanzemaljskih tijela (poput asteroida) o površinu planeta. Sve nabrojano već je samo po sebi prilično izvanredno, no život u cjelini (naročito neke vrste i ekosustavi) u prošlosti je odigrao ključnu ulogu u oblikovanju bio-fizičkih uvjeta na planeti (primjerice, slučaj porasta udjela visoko korozivnog kisika u atmosferi)

\footnotetext{
${ }^{2}$ Mladen Stilinović. Nobody wants to see ("Tri najbogatija čovjeka na svijetu posjeduju koliko i 600 milijuna najsiromašnijih"); http://universes-in-universe.org/eng/bien/istanbul_biennial/2009/tour/antrepo/mladen_stilinovic.

${ }^{3}$ Brojni drugi termini predloženi su kao naziv za novo doba uzrokovano ljudskim djelovanjem, među ostalima i: era katastrofozoika, homogenocen i myxocen (od grčke riječi za sluz).
} 
(Catling 2005). Međutim, takve pojave smatramo nenamjernim posljedicama nerefleksivnih činitelja, koje su se protegle kroz dulja vremenska razdoblja.

Vratimo se na trenutak Wittgensteinovim jezičnim igrama: "mi" smo skloni vlastitu refleksivnu vrstu smatrati barem djelomice kolektivno svjesnom suvremenog potencijala za narušavanje svakodnevne stvarnosti. A najočitiji primjer tog narušavanja jest prekid složene interakcije između biofizičkog okoliša i čovječanstva koja podupire svakidašnje zdanje civilizacije. Iako je gotovo svaka civilizacija u zabilježenoj povijesti u nekom trenutku doživjela slom, često materijalno uzrokovan pretjeranim iskorištavanjem okoliša (Diamond 2005; Morris 2011; Montgomery 2012), u prošlosti se uvijek radilo o lokalnim i regionalnim fenomenima. $U$ današnjem gusto premreženom tehnološkom društvu, prijetnja sloma civilizacije je globalna - i u smislu posljedica, i u smislu uzroka (Ehrlich i Ehrlich 2012). Globalizirani karakter suvremenog društva sam po sebi predstavlja povijesno specifičnu situaciju (Burke III 2009): danas gotovo i ne postoji skupina ljudi koja se može smatrati uistinu neovisnom od civilizacije, ma koliko oni isticali da u njoj nevoljko participiraju. Globalno raspršeno čovječanstvo međusobno je povezano u civilizacijsku mrežu u kojoj lokalna previranja imaju globalne posljedice (Goldin 2013). Međutim, problematična situacija s kojom smo sada suočeni više je od posljedice domino efekta visokog stupnja ekonomske i kulturne međupovezanosti. Globalno "Mi” koje efektivno, ako ne i politički, tvori civilizaciju, u cjelini mijenja materijalne uvjete na planeti snagom geofizičke sile, iako je njegova unutarnja struktura obilježena golemim nejednakostima u fizičkom utjecaju i političkoj moći.

Jedna od prednosti refleksivnosti koju nam pruža jezik jest mogućnost osmišljavanja i istraživanja protučinjeničnih (prošlih, budućih, nevidljivih ili apstraktnih) situacija te ocjene njihove poželjnosti na temelju sadašnjih iskustava. Iako takav model nikada nije savršeni nadomjestak za stvarna iskustva, on je upravo ono što bi, iz evolucijske perspektive, trebalo činiti razliku između ljudi i brzomnožećih bakterija koje izdišu plinove. Potpomognuti matematičkom racionalizacijom i snagom računala, ovakvi pojednostavljeni modeli već desetljećima upozoravaju na posljedice povećanja potrošnje od strane civilizacije preko granice sposobnosti regeneracije biofizičke raznolikosti na planetu iz sunčeve energije. Ono što je naročito zanimljivo kod recentnijih modela (Motesharrei, Rivas i Kalnay 2014) jest činjenica da, u usporedbi sa zasebnim djelovanjem pojedinačnih pokretača sloma, kombinacija osiromašenja resursa i neumjerene nejednakosti radikalno ubrzava potpuni slom civilizacije. Nadalje, čini se da socio-tehnološka struktura, u kojoj je osiromašivanje resursa posredovano kroz siromašne, no kojime upravljaju i od kojega korist imaju izuzetno bogati, djeluje kao veo koji onima koji su najbolje pozicionirani da nešto poduzmu zakriva pogled na upozorenja o ubrzanom slomu. Kroz škodljiv spoj neumjerenog osiromašivanja resursa i neumjerene nejednakosti, kao vrsta gubimo naš refleksivni potencijal, što nas čini više nalik bakterijama proizvođačima kisika iz geološki daleke prošlosti. To je razlog zašto ovoga puta moramo iskreno povikati “Vuk!” i u potpunosti prihvatiti da živimo u zaista izvanrednim vremenima.

\section{"Očajno, ali ne i ozbiljno" - akademska ekspozicija}

Koristeći svakodnevni jezik, odmaknut od apstraktnih matematičkih modela interakcija između čovjeka i prirode, moramo razgovarati o materijalnim i pogodnostima povezanim s radom koje suvremena civilizacija nudi većini populacija na razvijenom Sjeveru i Zapadu. To uključuje kuće, automobile i računala pomoću kojih se razmjenjuju tekstovi poput ovoga, pi- 
smenosti posvećeno vrijeme njihove razmjene. Dostupnost obilne jeftine energije dobivene iz fosilnih goriva oslobodila je moderna društva obimnog fizičkog rada nužnog za održavanje civilizacije, omogućila nam da vodimo produktivnije živote i proporcionalno smanjila razinu tjelesnog nasilja štetnog za pojedinca (Wills 2013). Istodobno, ona nemjerljivo doprinosi ireverzibilnim globalnim promjenama klime, ubrzavajući na taj način potencijalni slom suvremenih ljudskih civilizacija širom svijeta (Ehrlich i Ehrlich 2013). Bez obzira na taj temeljni paradoks energije i kulture, ni "razvijena" ljudska društva ne odustaju od ideje da njihovo sveopće blagostanje ovisi o njihovoj sposobnosti da globalnu proizvodnju dobara i usluga godišnje uvećavaju za barem 5\%, unatoč jasnim znacima da spomenuta praksa vodi u propast (Graeber 2011). Nužnost obećavanja povećanja dobara i usluga kao preduvjet nade u blagostanje populacija političkih jedinica (država, manje ili više labavih federacija i slično) stoga se nameće kao važno pitanje razvoja u dvadeset prvom stoljeću.

Najvjerojatniji odgovor na ovo pitanje glasi da u ovom trenutku svi članovi društva, jednakih potencijala i nominalno jednakih prava, nemaju jednak pristup dobrobitima koje se dobivaju iz resursa i energije te pretvaraju u dobra i usluge. Dobrobiti su trenutno oskudne, no kako se s vremenom budu povećavale, pretpostavlja se da će ih biti više za sve. Međutim, društvene strukture zadužene za raspodjelu spomenutih dobrobiti ne samo da ne smanjuju nejednakost na globalnoj razini, već je dodatno pogoršavaju, pojačavajući time osjećaj onih koji nemaju da je potrebno stvarati još više kako bi i oni mogli dobiti svoj dio kolača. Valja naglasiti da se, gledano iz globalne perspektive, posljednja rečenica ne odnosi toliko na osobe lišene hrane, skloništa ili lijekova, koliko na one kojima je uskraćen široki spektar druge potrošne robe. Dugovima pokretan put uvijek rastuće proizvodnje potrošne robe već bi sam po sebi bio problematičan (Graeber 2011), no sada je uparen s nadolazećom kritičnom točkom ireverzibilnih klimatskih promjena.

Više akademski nastrojen odgovor također bi ukazao na to da struktura financiranja proizvodnje u kapitalizmu, koja ovisi o posuđivanju s kamatama i istovremenoj proizvodnji dobara u neprestanom nadmetanju s drugim proizvođačima, iz nužde forsira rast BDP-a i potrošnje resursa, kako bi bila u stanju financirati izvorni dug na koji plaća kamate. Je li moguće osmisliti dovoljno velika i stoga održiva društva čije blagostanje neće ovisiti o redovnom povećanju proizvodnje dobara i usluga?

Meta-procjene istraživanja u fizičkim i društvenim znanostima, poput onih koje su objavile radne skupine Međuvladinog panela o klimatskim promjenama (eng. Intergovernmental Panel on Climate Change, skrać. IPCC; http://www.ipcc.ch/report/ar5/index.shtml), upozoravaju na ozbiljne ireverzibilne materijalne promjene kojima se nismo u stanju prilagoditi, a koje će nastati u slučaju porasta prosječne površinske temperature više od $4^{\circ} \mathrm{C}$ iznad temperature $u$ predindustrijskom razdoblju (upravo nas $u$ tom smjeru vodi aktualni model razvoja). Drugim riječima, ukoliko ne ublažimo uzroke globalnih klimatskih promjena, naša civilizacija vjerojatno se neće moći prilagoditi klimatskim i biofizičkim promjenama koje će uslijediti. Sudeći prema znanstvenom i kulturnom razvoju u posljednjih nekoliko tisućljeća, mogli bismo ustvrditi da će način na koji svijet funkcionira danas dovesti do toga da u nekoj bližoj budućnosti "svijet" više neće postojati. To ne znači da čovječanstvo neće postojati, već da će civilizacija koju su ljudi proteklih tisućljeća razvijali i kojom tumačimo vlastito blagostanje i okolišs, odumrijeti uslijed iznenadnog nestanka njenih biofizičkih temelja (usjevi, resursi i meteorološki obrasci). Ne samo da se baza fizičkih resursa troši brzinom koju inovativni nadomjesci za resurse ne mogu pratiti, već su i ekosustavi u kojima se odvija kruženje hranjivih tvari i o kojima ovisi ljudska vrsta također pred slomom. 
Dobar primjer sposobnosti prilagodbe i ishoda sloma nalazimo u moru, primarnom staništu planeta koji kao ljudi nastanjujemo samo periferno (i stoga smo ga u manjoj mjeri svjesni), no spremno ga iskorištavamo za hranu i biološke resurse. Posljednjih desetljeća mnoge regije postupno gube riblje resurse i bivaju preplavljene drevnim i učinkovitim, često žarećim i neprijatnim meduzama. Dok nas porast ljudske populacije i vlastiti tehnološki podvizi navode na neumjereno iskorištavanje ribljih zaliha, drevni i otporni organizmi poput neprijatne meduze (u smislu zrele faze u životnom ciklusu meduza) napreduju i stvaraju eutrofikacijske mrtve zone nepogodne za ljudsko iskorištavanje. Neki organizmi, poput meduza, savršeno su sposobni napredovati u zonama u kojima ekosustavi koji su se razvijali usporedo s čovjekom postaju nepostojani i propadaju; međutim, u tim (pro)palim zonama nema mjesta za ljude kakvi smo mi danas.

Ipak, zahvaljujući njihovoj sposobnosti da u slučajevima oskudne podrške unutar ekosustava u kojima žive "od-rastaju” čak i pojedinačna tijela (Gershwin 2013), ti nas organizmi mogu štošta naučiti. Podnoseći samonametnuta ograničenja rasta, na razini vrste oni, u osnovi, preživljavaju u nepromijenjenom obliku. Primjer meduze pokazuje kako život općenito može prevladati iznenadne poremećaje unutar ekosustava koji su se postupno razvijali (jer meduze su ujedno žive), ali i koliko negostoljubivi prema ljudskom napretku ti osiromašeni ekosustavi mogu biti. Ne samo da meduza (u smislu zrele faze u životnom ciklusu vrste) može opeći: meduze kao vrsta istiskuju druge oblike života i začepljuju tehnološku opremu koja se koristi u morskoj vodi. Izuzetno su otporne na sredstva kojima se čovjek bori protiv njih i većinu vremena ponašaju se poput bilo koje druge slijepe geofizičke sile: jednostavno plutaju nošene strujama.

Pojednostavljeno rečeno, čovječanstvo može nastaviti po starom i nadati se najboljem dok istraživači u pojedinim disciplinama znaju da srljamo u propast, ili napraviti korjeniti zaokret prema održivosti, oslanjajući se na naše kolektivno znanje i nastojeći povratiti i održati "zelenu ravnotežu” (Wills 2013) o kojoj ovisi naše individualno blagostanje, koliko i o zraku ili društvenoj suradnji (Wilson 2012). Lekcija koju možemo naučiti iz ovog biološkog koncepta jest ta da stabilni, životni, obilni, raznoliki i otporni ekosustavi nastaju uslijed široke palete okolišnih pritisaka i bioloških komponenata: pretvorbe sunčeve energije u biološke strukture, grabežljivaca i plijena, parazita, geofizičkih događaja. Niti jedno stanje "zelene ravnoteže” nije trajno. Usporedo s promjenom pritisaka koji utječu na relativnu učestalost populacija pojedine vrste unutar ekosustava mijenjaju se i njihove ekološke strukture i genetske ravnoteže.

Međutim, brojne vrste unutar ekosustava koje su (u evolucijskom smislu) imale dovoljno vremena da dosegnu uravnotežujuću ulogu najčešće su obilježene visokim stupnjem ekološke raznolikosti, kao i genetske raznolikosti unutar vrste. Kao vrsta i kao djelić slagalice "zelene ravnoteže" u pričuvi imaju mnoštvo rezervnih opcija za razdoblja mijena. Rječnikom biologije, za vrijeme promjena u fizičkom okolišu biološke vrste koje ga nastanjuju mogu se osloniti na spomenute raznolikosti kako bi povećale izglede da će neki od članova ekosustava preživjeti promjene. Raznolikost pridonosi općoj otpornosti sustava. No ljudske sile antropocena narušile su mnoge od postupno razvijenih "zelenih sustava ravnoteže”, smanjujući pritom raznolikost ekosustava iz kojih crpimo resurse. Budući da nisu razvijeni do te mjere da bi se mogli nositi s pritiscima svojstvenim vrlo recentnom antropocenu, ti ekosustavi nakon određene točke više ne mogu koristiti vlastite zalihe rezervnih opcija kako bi povratili stabilnost sustava u cjelini.

Kao istraživači, edukatori i inovatori (bilo društveni ili tehnološki), moramo biti svjesni činjenice da naša vrsta sudjeluje u procesima na bitno različitim razinama koje su u pravilu 
u oblastima odvojenih diskurzivnih disciplina: dinamika neživih Zemljinih sustava, povijest života i ljudske evolucije, povijest globalizirane industrijske civilizacije i kolektivna intelektualna kreativnost čovjeka čija svakodnevna egzistencija više ne ovisi o tjelesnim naporima (McNeill i McNeill 2003). Naš je zadatak pronaći glas koji dopire iz perspektive opkoračenja tih različitih razina. Nakon što je sva literatura proučena, a tekstovi napisani i pročitani, jasno je da čovječanstvo kao vrsta od sedam milijardi jednakih jedinki više nema mogućnost povratka u "prirodno stanje" obilježeno sretnim i blaženim neznanjem. Povijesno stanje u kojem nas sedam milijardi istovremeno egzistira na ograničenom planetu ili vodi u bolan slom ili predstavlja civilizaciju - nužno mnogostruku, dinamičnu i složenu (Pagden 2013). I nekada i sada, civilizacija podrazumijeva neki oblik koordinacije i podčinjavanja. Ona je spoj svijesti o fizičkim i društvenim granicama razvoja, i tehnoloških i političkih instrumenata koji upravljaju razvojem unutar tih granica. To se doima prilično očitim, no kako na prihvatljiv način smanjiti nesigurnosti i promovirati emancipaciju?

\section{Povijest komponenti razvoja: nedostaci tehnološkog rješenja}

Kao obrazovane osobe, naučeni smo ponositi se činjenicom da pripadamo vrsti koja ne samo da je stvorila civilizaciju, već je, zahvaljujući ingenioznosti tehnološkog otkrića, u tome uspjela pomoću rastuće učinkovite uporabe prirodnih resursa. Ova vrsta narativa zanemaruje druge nužne komponente izgradnje civilizacije koje se razvijaju usporedo s tehnologijom, te predstavlja osnovu za uzaludnu nadu u to da će tehnološka ingenioznost (učinkovit i čist izvor energije) riješiti i naše sadašnje probleme.

Većina onoga što je proizvelo civilizaciju kakva postoji danas rezultat je "razvojnog projekta”: izgradnje država, sedentarizacije i pojačanog iskorištavanja dostupnih resursa (Pomeranz 2009) - mnogostrukosti na kojoj počivaju blagodati civilizacije. To je dovelo do porasta prosječne očekivane životne dobi i poboljšanja općeg fizičkog zdravlja, kao i porasta broja stanovnika, ali ne i do automatski pravedne raspodjele spomenutih blagodati. Opsežni povijesni narativi navode sljedeće osnovne ontološke kategorije razvojnog projekta: 1) tehnološki mehanizmi pretvorbe energije, 2) društvene strukture koje koriste spomenutu energiju i održavaju tehnološke mehanizme, te 3) upravljački mehanizmi koji nadgledaju i održavaju uporabu energije društvene strukture.

Spomenute strukture opisuju dugotrajne procese ostvarenja razvojnog projekta, a ne konkretna društva i civilizacije koje utjelovljuju suvremene ishode tog projekta u danom trenutku. Ipak, takvo modeliranje u stilu seta za gradnju "Meccano" ovdje je važno samo kako bi nam skrenulo pažnju na činjenicu da potencijal za ponovnu uspostavu cjelokupne globalne ravnoteže ne leži u modifikaciji samo jedne od spomenutih komponenata (1-3), jer postojeći se problem razvijao kroz kontingentne promjene u svakoj od triju komponenata. Porast broja stanovnika i materijalnog blagostanja doveo je resurse do krajnjih granica, što je rezultiralo time da su svugdje postupno postavljena ograničenja na količine energije dostupne za pretvaranje i korištenje za ljudske potrebe. U ne tako davnoj prošlosti (ujedno i najvažnija razvojna lekcija za suvremena društva), rizično oslanjanje na tehnološke promjene (komponenta 1), te imperativi rasta i centralizirane državne moći (komponente 1 i 3 ) dominirale su kako bi neprijatnu korjenitu promjenu društvene strukture (komponenta 2) učinile nepotrebnom, čak i unutar nominalno socijalističkih društava (Weiner 2009). 
Raskorak između dugoročne stabilnosti ekosustava i ljudske populacije, uzrokovan manjkom biomase kao energetskog i građevinskog resursa te iscrpljivanjem plodnosti tla, nalazimo već u ranom modernom dobu, u dominantnim civilizacijama Istoka i Zapada (Pomeranz 2000). Često se odveć pojednostavljeno pretpostavlja da je parni stroj čudesno otkriće koje je (zapadnjačkim) društvima rane moderne Europe omogućilo da se intelektualnom ingenioznošću izbave iz ekološki problematične nejednakosti na relaciji stanovništvo-energija-hrana. Primijenivši Razum, poduzetni je čovjek otkrio tajne namjerno skrivene u fizičkim procesima što mu je omogućilo da iz naizgled osiromašene fizičke podloge izvuče mnogo više koristi. Međutim, opsežnije analize (npr. De Vries 1993; Pomeranz 2000; Arrighi et al. 2003) otkrivaju da se zapadnjački razvojni projekt održao i razvijao u smjeru koji vodi u opasnu i problematičnu situaciju u kojoj se trenutno nalazimo, slijedeći pritom vrlo kontingentan put teritorijalnog širenja i manje ili više namjernih transformacija društvenih struktura i upravljačkih mehanizama koji teku paralelno s, a katkad i prethode, tehnološkim otkrićima. Razvojni put Istočne Azije (s vremenom istisnut ili inkorporiran u ranije spomenuti konkurentni zapadnjački razvojni put) nije bio ništa manje učinkovit po pitanju pretvorbe energije (1) kao ni njenog rebalansiranja unutar ukupnih ograničenja populacije i hrane. $U$ dominantnim ranim modernim civilizacijama Istoka na snazi su bile drugačije kombinacije društva (2), tehnologije (1) i uprave (3), što je dovelo do drugačijeg rješavanja neravnoteže na relaciji ekosustav-populacija, sve do globalnog širenja fosilnim gorivima pokretanog zapadnjačkog oblika razvoja.

Od industrijskog doba, razvojna se paradigma na Zapadu oslanjala na širenje kapitalističkog oblika proizvodnje, tvoreći pritom većinu materijalnih temelja onoga što ljudi danas nazivaju civilizacijom. Čak su i eksperimenti dvadesetog stoljeća s alternativnim oblicima ekonomske organizacije u vidu državnog socijalizma također nepokolebljivo jurili za ekonomskim rastom i tehnološkom intenzifikacijom pretvorbe energije kao pokretačima nade u blagostanje (Weiner 2009). Slično spomenutim pretjerano pojednostavljenim pretpostavkama o revoluciji mehanizama pretvorbe energije (1) potaknutoj tehnološkom uporabom ugljena kao fosilnog goriva, i danas postoji nada u tehnološko rješenje. Međutim, povijesni dokazi o uspješnom smanjenju emisije stakleničkih plinova koji uzrokuju klimatske promjene na razini čitave države ne postoje, uz izuzetak povijesnog sloma industrijskog društva Ruske Federacije od devedestih godina prošloga stoljeća. To zasigurno nije bio tehnološki napredak, već tehnološka regresija popraćena drastičnim promjenama u društvenim strukturama (Hoffman 2011).

Povijesno gledano, također svjedočimo golemom povratnom efektu tamo gdje je ostvareno povećanje učinkovitosti resursa ("energija više nije prljava što nam daje pravo da koristimo veće količine energije”), te vrlo malom ili nikakvom smanjenju okolišnog utjecaja po jedinici proizvedene energije duž čitavog lanca tehnoloških zaliha pretvorbe energije. Jednom kad je uspostavljen, određeni tehnološki mehanizam može proizvoditi “čistu energiju”, no to ne znači da je do te faze stigao u obliku dovoljno čistom da opravda nadu u tehnološku revoluciju koja samostalno uklanja ograničenja klimatske promjene. Novi mehanizam pretvorbe energije, oslobođen ograničenja klimatske promjene, društvo neće nužno opskrbljivati energijom na način na koji to trenutno čine fosilna goriva. Raspodjela energije kroz društvene strukture u razvojnom procesu mijenjat će se usporedo s njim, kao što je to slučaj s postojećim obnovljivim izvorima solarne i energije vjetra koje ovise o vremenu i geografiji te ih nije moguće transportirati na isti način kao i fosilna goriva.

Naposljetku, pretpostavimo da je pronađen novi mehanizam pretvorbe energije: da bi postigao željeni učinak na klimatske promjene, valjalo bi ga vrlo brzo distribuirati diljem go- 
leme i rastuće ljudske populacije (Hoffman 2011). Teško je reći bi li takva vrsta distribucije bila moguća bez značajnih modifikacija postojećih upravljačkih mehanizama i društvenih struktura raspodjele energije. Iako smo tehnološki razvijeniji i politički međupovezaniji nego ikada prije, jesmo li u stanju spustiti ugljični intenzitet ljudske populacije ispod predindustrijskih razina, istovremeno održavajući broj stanovnika deset puta veći od populacije u predindustrijskom dobu, mijenjajući pritom jedino dominantne tehnološke mehanizme pretvorbe energije, i to unutar polovice prosječnog životnog vijeka (trideset do četrdeset godina)?

[Tehnologije] razvijene u svrhu rješavanja jednog problema na kraju nerijetko stvaraju niz novih, često nepredviđenih problema. [... Sve predložene] vrste "rješenja" utemeljenih na tehnologiji izuzetno su kontroverzne i rizične, a sa sobom nose i opasnost ozbiljne štete za okoliš. Pretjerana usredotočenost na tehnologiju također često zamjenjuje jednostavna ali učinkovita rješenja problema i potvrđuje uvjerenje da [druge strukturne promjene] nisu nužne za smanjenje ljudskog utjecaja na planet. (Tienhaara 2009: 18)

Sve dok je dostupne energije u fizičkoj okolini planete Zemlje, i dok tu energiju treba pretvarati u korisne oblike i potom tehnološkom ingenioznošću transportirati, uzalud se nadamo "otkriću" dovoljno raširenog i učinkovitog mehanizma do kojega će doći na vrijeme da se spriječi kolaps. Postojanost civilizacija - mnogostrukih, dinamičnih i složenih - iziskuje pravovremene i domišljate prilagodbe društvenih struktura i upravljačkih mehanizama kako bi se nadoknadili propusti mehanizama pretvorbe energije za kojima se posegnulo zbog njihovog potencijala održivosti. Kako bi to moglo izgledati u praksi? Pri planiranju krenimo od spoznaje da drastične pretvorbe energije fosilnih goriva treba ograničiti: trebamo globalno ograničenje emisije stakleničkih plinova.

\section{Kapitalizam kao društvena struktura u razvoju?}

Neravnotežom između ekosustava i populacija na Istoku u ranom novovjekovnom razdoblju bavili su se radno intenzivni razvojni projekti koji nisu bili fokusirani na teritorijalnu ekspanziju potpomognutu tehnološkim prevladavanjem ograničenja pretvorbe energije (Wood 2002; Pomeranz 2000), što je bio slučaj u "radišnom" razvoju Istoka (Sugihara 2003). Dok se povjesničari trude objasniti kontingencije koje dovode do razdvajanja razvojnih putova između Istoka i Zapada od ranog novog vijeka naovamo, za potrebe ove rasprave dovoljno je istaknuti da "razlog tome ne leži u činjenici da je progresivni Zapad otkrio kapitalizam, a moderna država i Kina nisu” (Rowe 1990: 262). Postoje i primjeri okolišnih resursa kojima se upravlja putem zajedničkih dobara (eng. commons) koja zadovoljavaju ekonomske potrebe ljudske populacije bez da ih se prekomjerno iskorištava ili da stvaraju neproporcionalnu akumulaciju među njihovim korisnicima. Iako te alternative ne dovode do maksimalnog uvećavanja dobiti i često se namjerno ostvaruju na lokalnoj, a ne globalnoj razini, one kombiniraju materijalnu korist s održivošću okoliša te kao takve mogu imati smisla i u "zapadnjačkom" kontekstu (Pomeranz 2009). Treba očekivati da tehnološke (1), društvene (2), ali i upravljačke (3) inovacije mogu proširiti razinu prošlih zajedničkih praksi. Možemo li, oslanjajući se na opsežno znanje o prirodnim i društveno povijesnim procesima, postići da globalna populacija ima koristi od ranije lokaliziranih alternativa?

Kapitalizam, kao kontingentan ishod specifičnih povijesnih uvjeta, počiva na imperativu neprestane samoekspanzije ukorijenjenom u sveobuhvatnoj transformaciji metaboličke 
razmjene s ostatkom biosfere i raspodjelom nasušnih životnih potreba unutar ljudskih društava (Wood 2002). Njegov imperativ rasta dobro se povezao s lokaliziranim nadilaženjem bio-fizičkih ograničenja putem inovacija fosilnih goriva u tehnološkim mehanizmima pretvorbe energije (Rundgren 2013). Drugim riječima, parni stroj i teritorijalna ekspanzija s ciljem pronalaženja ključnih resursa podupirali su jedno drugo. No dvojbeno "pobjedničku" formulu omogućilo je izostanak "neprijateljstva prema bilo kojem pojedincu koji postaje 'abnormalno' bogat” (Braudel 1982: 589) od strane upravljačkih tijela. Nadalje, karakteriziraju je i pravilni trendovi stagnacije i opadanja, s pripadajućim smanjenjem okolišnog utjecaja i povećanjem egzistencijalnog jada čovječanstva (iako ta veza nije uvijek bila linearna, djelomično zbog one vrste "izvan-ekonomskih" uplitanja kakvu bi društvene i upravljačke promjene mogle nametnuti i u sadašnjoj situaciji (Wood 2002: 93). Sada kad se širenje u teritorijalnom i materijalnom smislu ne može nastaviti, čudotvoran tehnološki proboj na polju pretvorbe energije još uvijek se ne nazire, a velik dio tehnologije koja potiče slom je već ugrađen u svakodnevicu, demokratizacija i strateški od-rast (eng. degrowth) ekonomija te promjene u raspodjeli dohotka ostaju jedine dostupne opcije za razvojni projekt na kojem temeljimo civilizaciju.

Uz kreativno-destruktivne učinke kapitalizma na društvene strukture, rašireno izvlašćivanje, intenzivnu eksploataciju i nemoralni nemar prema ljudskom životu u interesu profita, upravo se proizvodnost orijentirana na profit, a ne strukturna novina tehnoloških mehanizama, inicijalno manifestirala u vidu neodgovorne uporabe zemljišta i smanjenja regenerativnog kapaciteta biosfere (Woods 2002). Proizvodnost orijentirana na profit, a ne široka raspodjela dobrobiti, pokrenula je postojeći trend neodrživosti, imperativ rasta zaodjenut u obećanje emancipacije. To je samo po sebi bila nasilna, ne tek evolucijska, promjena društvenih struktura, koja se morala nametnuti odozgo, od strane onih članova društva koji su od nje imali najviše koristi (Hobsbawm 1952). Umjesto da se jednostavno pojavi nakon što su parni stroj i financijski kapital postali dostupni, za nj su se aktivno morali boriti članovi društva koji su u njoj prepoznali vlastite neposredne interese. I to nisu bili tek građani željni raznolikije ponude pamučnih tkanina i zemljanog posuđa, već mnogo opakiji pojedinci (Rundgren 2013). Njegovo nametanje ne-zapadnjačkim, "nerazvijenim" društvima i dalje izaziva otpor. Čak je i "razvijenim” demokratskim populacijama cilj oduprijeti se tehnološki riskantnim strategijama ekonomskog rasta, a povećanje plaća iznad određene granice nije im poticaj da rade više (Barry 2012). Globalno gledajući, kapitalistički imperativ rasta štetan je mehanizam koji se hrani rastućim nejednakostima i skriva iza obećanja o rastu na poljima obrazovanja, zdravlja, komunikacije i proizvodnje hrane za one kojima je to najpotrebnije.

Daleko od toga da zagovaramo povratak predmodernim poljoprivrednim društvenim strukturama, koje same po sebi također predstavljaju ishod razvojnih projekata, a ne dobrohotno "prirodno stanje"; pretpostavimo radije da odgovor na trenutnu prijetnju sloma leži u svrhovitoj reorganizaciji (2) društvenih struktura i (3) upravljačkih mehanizama. Te dvije komponente civilizacije trebale bi se usredotočiti na održavanje njenih dobrobiti u kombinaciji s mnogostranim transformacijama tehnologije pretvorbe energije koje su postojeće, jednostavne i učinkovite (Tienhaara 2009). Iako smislena u kontekstu zajednica i političkih jedinica, to je promjena koju valja primijeniti na globalnoj razini. Ovaj opći uvjet proizlazi iz globalne prirode klimatskih promjena, globalnih mehanizama koji realiziraju ranije opisani slom civilizacije prema formuli: "osiromašivanje resursa + nejednakosti" (Motesharrei, Rivas i Kalnay 2014) te činjenice da je razvojni projekt sada globalno vezan uz jedinstveno, globalno, kapitalističko društvo ovisno o fosilnim gorivima (Arrighi et al. 2003). 
Možda najvažnija lekcija povijesne procjene kapitalizma kao kontingentnog ishoda razvojnog projekta (Wood 2002; Pomeranz 2000; Sugihara 2003) jest da kada se kapitalistički mehanizmi za društvenu reprodukciju i razvoj jednom uspostave na određenoj lokaciji, oni neizbježno transformiraju sve ostale. Kapitalizmu svojstvena logika ekspanzije s vremenom prisiljava druga ljudska društva s kojima dolazi u kontakt da se i sama okrenu eksploataciji ljudi i okoliša, što dodatno govori u prilog potrebi prepoznavanja globalnog karaktera suvremene krize. Osim toga, iz toga proizlazi da bi preobrazba društvene strukture i upravljačkih mehanizama trebala bili sadržajnija od ublažavanja etike profita pomoću "socijalnog tržišta" ili "tržišnog socijalizma” (Wood 2002: 195). Imperativ rasta širi se brže čak i od ideologija kojima se opravdava, a nada u "zeleni rast" donosi mnogo lažne nade i isprika za nedjelovanje u kritičnim trenucima izvanrednih vremena (Hoffman 2011).

\section{Kakva je vrsta transformacije potrebna da bi se izbjegao slom?}

Iako ne postoji univerzalan i široko dostupan izvor energije ili otkriće na polju tehnološke učinkovitosti koje bi trenutni rast populacije i profita zadržali unutar granica ravnoteže klime i ekosustava (Li 2008; Ehrlich i Ehrlich 2103), ipak postoji niz tehnoloških mehanizama manjeg opsega pogodnih za održivije crpljenje energije. Iako ne sugeriraju povratak u predmoderno doba, ove strategije uključuju transformacije društvene strukture i upravljačkih mehanizama kao i temeljitu reevaluaciju sastavnica koje tvore naše poimanje ljudskog blagostanja. Demokratizacija ekonomskih praksi, promjene u društvenoj raspodjeli dohodaka kao simbola pristupa pretvorbama energije te kultura koja civilizacijska postignuća ne povezuje s potrošačkim ponašanjem, transformativne su smjernice za teoriju razvoja u dvadeset prvom stoljeću.

Smješten na kraju dugog niza analiza pitanja što je neodrživo u našoj trenutnoj egzistenciji i odakle su (povijesno gledano) te karakteristike ponikle, ovaj tekst i njegova uloga u časopisu ne mogu biti drugo doli poziv na intelektualnu mobilizaciju povezanu s predviđenom budućnošću u koju tek trebamo zakoračiti. Povijesne analize u kombinaciji s apstraktnim modelima interakcije između osnovnih ontoloških kategorija na relaciji društvo-ekosustavi-resursi, otvaraju prostor za predviđanja u kojima bi se slom mogao izbjegavati u nedogled, a ljudska populacija dovesti u stanje stabilne ravnoteže s ostatkom globalnog ekosustava, pod uvjetom da stopa crpljenja resursa za pretvorbu energije po glavi stanovnika ostane na prirodno obnovljivoj razini, a dobrobiti dobivene tim crpljenjem budu distribuirane na relativno pravedan način (Motesharrei, Rivas i Kalnay 2014). S druge strane, ta predviđanja istodobno sugeriraju da pretjerano crpljenje i povećanje nejednakosti vrlo vjerojatno vode do relativno brzog sloma (Meadows, Meadows i Randers 1972; Motesharrei, Rivas i Kalnay 2014), što je isprva nevidljivo vrhovnim krugovima zaštićenima vlastitim bogatstvom, sve dok kolaps ekosustava ne uzrokuje vidljivi kolaps primarnih proizvođača (Motesharrei, Rivas i Kalnay 2014). U tom će trenutku biti prekasno za promjene.

Iako bi kolaps postojeće globalne civilizacije razvojni projekt - zajedno s njegovim po okoliš štetnim, ali i za ljude oslobađajućim ishodima - zaustavio na mjestu, čovjekovo intelektualno opkoračenje procesa bitno različitih redova veličine dopušta nam da osmislimo projekt održivog od-rasta (Kallis 2011). Razvojni projekt do sada nije djelovao u stanju ravnoteže, no načelno ne postoji ništa što bi ga priječilo da to stanje i postigne, baš kao što i nove vrste s vremenom postižu novo stanje "zelene ravnoteže" sa stabilnim ekosustavima. To je 
povijesni zaokret na razvojnom putu, politički projekt transformacije globalnih upravljačkih mehanizama i reevaluacije blagostanja pojedinca. To je vizija civiliziranog društva u kojem su produkti pretvorbe energije skromniji i stabilniji, a blagostanje počiva na jednakosti, međuljudskim odnosima i jednostavnosti. Kao tvorci narativa, akademski građani i istraživači pozornost čovječanstva moraju skrenuti na procese koji se odvijaju na ne-ljudskim razinama, i ovoga puta pokušati to učiniti na emancipirajući način kako bi omogućili civlizacijski odrast bez uništavanja dosadašnjih (tehnoloških i društvenih) postignuća.

Iz svega rečenog valja upamtiti tri važne stvari. Prvo, važno je samoga sebe pripremiti za usvajanje stajališta iz kojega je moguće prihvatiti mogućnost dramatičnog poremećaja toka povijesti (kolaps). Drugo: trebamo shvatiti da je put koji vodi u to stanje stvar kontingentnih povijesnih odabira, bez obzira na to što je utjecaj koji su pojedinci imali i još uvijek imaju na njih malen. Naposljetku, važno je shvatiti da su materijalna ograničenja promjene klime i osiromašivanja resursa, te društvena ograničenja nejednakosti inherentna idealu neograničenog ekonomskog rasta, "lice i naličje istog novčića" (Beck 2010: 257). Kad bismo se ozbiljno postavili u poziciju budućeg sloma kao da ga već doživljavamo, sa znanjem o povijesnim kontingencijama i nužnoj interakciji između tehnoloških i društvenih komponenata doprinosa razvojnog projekta izgradnji civilizacije, mogli bismo, svjesno is afektivnom hitnošću, razmatrati prošle protučinjenične opcije: "Da smo napravili ovo ili ono, nikada ne bi došlo do katastrofe u kojoj se trenutno nalazimo!” (Žižek 2008: 461). Iz takve vizije proizlazi istinska snaga potrebna za kidanje spona pojedinačne beznačajnosti: pokrenite se i djelujte danas kako bismo izbjegli slom. Dobrodošli u razmišljanje za dvadeset drugo stoljeće! 


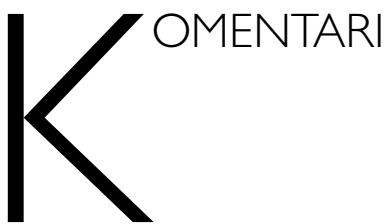

\section{Danijela Dolenec Grupa 22, Zagreb}

\section{Hvatanje u koštac s opakim problemom: promicanje alternativnih poimanja blagostanja na putu ka održivom od-rastu}

Kada su Rittel i Webber prvi put definirali “opaki problem” (1973), na pameti im nisu bila naša trenutna nastojanja da pronađemo društveno održiva rješenja za probleme globalnog okoliša. Oni su gradili opći argument o granicama strateških reakcija na važne društvene probleme, a cilj im je bio skrenuti pozornost na činjenicu da klasična znanstvena paradigma koja čini temelje modernog poimanja razvoja nije primjenjiva na društvene probleme. Za razliku od problema unutar prirodnih znanosti koje je "moguće definirati i razdvojiti, i koji mogu imati rješenja koja možemo otkriti”, glavni društveni izazovi današnjice nisu ništa od navedenog. Ključna razlika među njima vjerojatno leži u činjenici da društveni problemi nemaju rješenja: s obzirom na to da ovise o ishodima političkih borbi, u najboljem slučaju može ih se uvijek iznova rješavati (ibid.).

Taj koncept opakog problema nedavno je primijenjen na promjenu klime (Levin et al. 2012) kojoj su pritom pripisana četiri ključna obilježja: vrijeme istječe; oni koji stvaraju problem ujedno nastoje pronaći rješenje; središnji autoritet koji bi se trebao uhvatiti u koštac $\mathrm{s}$ problemom je slab ili nepostojeći; iracionalno negiranje problema odgađa pronalaženje rješenja za neka buduća vremena. Navedena obilježja rezultiraju najnovijom verzijom dobre stare tragedije zajedničkog dobra (eng. tragedy of the commons): unatoč tome što je jasno da je nužno odmah djelovati kako bi se izbjegle katastrofalne posljedice u budućnosti, vlade ne reagiraju. Najnoviji izvještaji IPCC-a (2014) jasno navode da bez brzih i ozbiljnih napora usmjerenih ka ublažavanju postojeće situacije, ljudska društva neće biti u stanju prilagoditi se nadolazećim klimatskih i biofizičkim izazovima.

Opisivanje klimatskih promjena kao opakog problema jedna je od početnih tvrdnji kojima Domazet nastoji usmjeriti našu pozornost na hitnost zadatka koji je pred nama, polazeći od pretpostavke da dijelimo njegovo uvjerenje da ljudsku civilizaciju, u njenom trenutnom obliku, vrijedi sačuvati. I sama polazim od te pretpostavke, iako priznajem paradoksalnu činjenicu da je unatoč tome što refleksivnost smatramo jednim od obilježja koje nas razlikuje od ostalih vrsta na Zemlji, naš utjecaj na planet postao nalik onome geofizičkih sila poput pomicanja tektonskih ploča ili vulkanskih erupcija (Archer 2010). Budući da je naš fizički utjecaj na planet dosegao točku u kojoj više nismo u mogućnosti nastaviti vlastitu teritorijalnu i materijalnu ekspanziju, trebali bismo napustiti naivnu nadu u tehnološko rješenje i priznati da opakost tog problema iziskuje nadilaženje tehnokratskog prtljanja rascjepkanog na tradicionalne akademske discipline, i prihvaćanje dubinski ambicioznog političkog projekta korjenitog zaokreta prema održivosti (Wills 2013).

Drugim riječima, valja priznati da je zaokret prema održivosti u svojoj biti društveni izazov, koji u prvom redu uključuje promjene društvenih praksi, institucija i upravljačkih meha- 
nizama, primjenom načela demokratizacije, egalitarne preraspodjele i od-rasta. Naš zadatak kao "tvoraca narativa" (usp. Domazet) stoga je apsurdno ambiciozan: sastoji se, ni manje ni više, nego od ponovnog osmišljavanja razvojnog projekta koji bi blagostanje čovječanstva uskladio s praksama koje jamče našu materijalnu održivost na planeti. Kao prvi korak u rješavanju zadatka tako divovskih razmjera vidim jedino kombiniranje velikih ideja sa skromnim praktičnim prijedlozima. Levin et al. (2012) predlažu osmišljavanje strategija koje će "ograničiti naša buduća kolektivna jastva”, što podrazumijeva interveniranje u naše društvene i političke prakse na načine koji su trajni tako da s vremenom postanu ukorijenjeni i sve čvršće se primaju. Kako započeti?

Slon u sobi koji povezuje naš fizički utjecaj na planet s društvenim ograničenjima nejednakosti jest kapitalizam, neraskidivo povezan s principom bezgraničnog ekonomskog rasta (Wood 2002). S obzirom na to da je imperativ rasta strukturno obilježje kapitalizma u svim njegovim varijantama (Harvey 2007), u principu ne postoji način da se kapitalistički modus proizvodnje pomiri sa stvarnim zaokretom prema održivom od-rastu (Kallis 2011). Ono što nas čeka stoga je niz dubinskih promjena unutar naših temeljnih institucija koje upravljaju zemljištem, radom i novcem, usmjerenih ka ekonomskom sustavu kojeg više neće biti moguće okarakterizirati kao kapitalizam (ibid.). Međutim, s obzirom na trenutnu konstelaciju moći, stjecanje javne podrške za tranziciju tih razmjera u najmanju je ruku malo vjerojatno. Umjesto toga, u potrazi smo za rupama u sustavu u koje možemo umetnuti strateške prijedloge s potencijalno transformativnim učincima. Jedan takav prijedlog jest odvajanje (eng. decoupling) koncepta blagostanja od potrošačkog ponašanja, poglavito kroz zamjenu BDP-a kao mjere napretka alternativnim indikatorima blagostanja.

Iako je zamišljen isključivo kao mjera čiste tržišne ekonomske aktivnosti (Kubiszewski et al. 2013), BDP smo s vremenom prihvatili kao mjeru blagostanja. Nadalje, BDP svaki trošak tumači u pozitivnom svjetlu, ne praveći razliku između aktivnosti koje pridonose blagostanju od onih koje ga umanjuju (Talberth et al. 2007): tako naftni izljev posljedičnim troškovima čišćenja uvećava BDP, dok uzgoj povrća i priprema obroka u domaćinstvu ne ulaze u BDP jedne države. Nadalje, BDP ne otkriva ništa o raspodjeli dohodaka unutar društva, iako je to jedan od odlučujućih faktora za određivanje individualnog blagostanja (Wilkinson i Pickett 2009).

Od objavljivanja izvještaja Stiglitza, Sena i Fitoussia o ekonomskoj učinkovitosti i društvenom napretku (2009), osmišljavanje alternativnih indikatora blagostanja i napretka koji bi bolje integrirali ekonomsku dimenziju s društvenom i okolišnom (Costanza et al. 2004) dobiva sve više zamaha. Posljednjih godina svjedočimo razvoju niza alternativnih mjerila kojima je cilj obuhvatiti aspekte ljudskog blagostanja, sigurnosti i kvalitete života, primjerice Indeks sretnog planeta ${ }^{4}$ (eng. Happy Planet Index), Indikator pravog napretka ${ }^{5}$ (eng. Genuine Progress Indicator) i Inicijativa za bolji život ${ }^{6}$ (eng. Better Life Initiative) Organizacije za gospodarsku suradnju i razvoj (eng. Organisation for Economic Cooperation and Development, skrać. OECD). U domaćem kontekstu, Grupa 22 oblikovala je analize ${ }^{7}$ koje, koristeći UNov Indeks ljudskog razvoja, Indeks ekoloških otisaka (eng. Ecological Footprint Index), te niz indikatora razine nejednakosti u prihodima (GINI, rizik od siromaštva, materijalna oskudica itd.), rasvjetljavaju razvojni put i buduće perspektive Hrvatske. Pokazali smo da su društva na europskoj poluperiferiji siromašnija, što bi, prema teorijskim očekivanjima (Franzen i

\footnotetext{
${ }^{4}$ Podaci dostupni na: http://www.happyplanetindex.org/.

${ }^{5}$ Podaci dostupni na: http://genuineprogress.net/.

${ }^{6}$ Inicijativa za bolji život OECD-a: http://www.oecd.org/statistics/betterlifeinitiativemeasuringwell-beingandprogress.htm.

${ }^{7}$ Vidi npr. We need to Change (2012), te nekoliko tekstova u nedavno objavljenom zborniku Sustainability Perspectives from the European Semi-periphery (2014).
} 
Mayer 2010), trebalo značiti manju vjerojatnost njihova djelovanja u smjeru zadovoljavanja okolišnih preduvjeta za zaokret prema održivosti (Domazet, Dolenec i Ančić 2012). Međutim, usprkos manjoj spremnosti na individualne materijalne žrtve, briga za okoliš i globalna empatija u takvim je društvima viša nego što njihova razina razvoja (mjerena BDP-om) daje naslutiti. Valja dodati i da je ovdje riječ o društvima s bitno nižim utjecajem na okoliš na globalnoj, često čak i na lokalnoj razini, društvima u kojima je povijesni imperativ poticanja globalnog zaokreta prema održivosti relativno manji.

$S$ obzirom na neravnomjernu raspodjelu blagodati ekonomskog rasta i razvoja u proteklih dvadeset godina, nejednakost predstavlja ključnu prepreku obuhvatnijem djelovanju. Smanjivanje nejednakosti, kao preduvjet za razvoj društvenih odnosa povjerenja i suradnje, stoga postaje prioritet. Ne možemo očekivati kolektivno djelovanje kada su materijalni životni uvjeti i životne prilike koje iz njih proizlaze toliko međusobno različiti da građane međusobno razdvajaju i guraju u različite socio-materijalne stvarnosti (Sandel 2012). Bez temeljnog osjećaja zajedničke ljudskosti nema ni demokratske debate o odlikama pravednog i održivog društva (Wright 2011).

Iako uvođenje alternativnih mjera blagostanja ne rješava sve naše probleme, kao nositelj transformativnog potencijala ono bi idealno trebalo predstavljati korak u pravom smjeru. S obzirom na vrstu njihova odnosa s temeljnim društvenim strukturama i ishode koje stvaraju, Fraser $(2000,2003)$ razlikuje afirmativne i transformativne strategije. Cilj afirmativnih strategija jest ispraviti neravnopravne ishode bez remećenja temeljnih društvenih struktura, dok su transformativne strategije usmjerene izravno na temeljni generativni okvir, što ih očito čini poželjnijima. Međutim, njih je istovremeno teže provoditi budući da su izuzetno osjetljive na probleme kolektivnog djelovanja. S obzirom na spomenuta obilježja, Fraser (2003) smatra da je nacrtima praktičnih strategija mjesto negdje duž kontinuuma između spomenuta dva pola.

Imajući sve što je rečeno na umu, ako je naš cilj transformirati naše ekonomske i društvene prakse do te mjere da ih se više ne može podvesti pod nazivnik "kapitalizma", možda je konceptualizacija alternativnih mjerila blagostanja jedna od odgovarajućih strategija za postizanje tog cilja. Ona, u svakom slučaju, nudi reorijentacije od mjerila dohotka i BDP-a prema konceptima dobrobiti i blagostanja, što u svom objašnjenju koncepta održivog od-rasta spominje i Kallis (2011). Uspješno odvajanje blagostanja od fiksacije na ekonomski razvoj moglo bi biti važan doprinos prihvaćanju od-rasta kao održive političke strategije. Kao što su mnogi autori već istaknuli, valja imati na umu da održivi od-rast nije isto što i negativan rast BDP-a. Tu pojavu, poznatu kao recesija, proteklih smo godina, nažalost, i predobro upoznali, kao i pripadajuću joj paletu negativnih društvenih posljedica poput nezaposlenosti, ekonomske nesigurnosti i društvenih prevrata. Nasuprot tome, održivi od-rast počiva na ideji da je rast ekonomije moguće smanjiti putem institucionalnih promjena, kolektivnim upravljanjem "udobnog puta prema dolje" (Odum i Odum 2001) kroz političke procese odlučivanja da se, primjerice, broj zrakoplova i automobila smanji u korist boljih socijalnih službi, širenja javnih prostora i povećavanja osobne autonomije. 


\section{Vladimir Cvijanović \\ Grupa 22, Zagreb}

\section{Institucionalne inovacije za novu ekonomiju}

Razumijevanje granica prevladavajućeg socio-ekonomskog sustava, pogotovo institucionalnih inovacija koje ispravljaju njegove glavne nedostatke, iziskuje poimanje sustava koje nije zajedničko svim školama ekonomskog mišljenja. Nadalje, budući da se definicije "nove ekonomije" razlikuju, mi ćemo spomenutu frazu koristiti u značenju ekonomije koja maksimalno uvećava blagostanje društva u cjelini, a ne tek pojedinih društvenih skupina. Jedan od mogućih pristupa, poznat po svojoj institucionalnoj i strukturalnoj perspektivi te historicizmu, nudi francuska teorija régulation, na koju ćemo se oslanjati u ovome radu.

Za Boyera, pristup régulation predstavlja istraživački program prikupljanja povijesnih studija, međunarodnih usporedbi i makro-ekonomskih testova s ciljem identificiranja nekih tipičnih konfiguracija razvojnih oblika i njihovih kriza. Smatra se da régulation nastaje u trenutku ublažavanja tih kriznih tendencija. (James 2009: 185)

Iako podroban opis pristupa régulation (eng. Régulation approach, skrać. RA) nadilazi okvire ovog rada, ovdje donosimo tek kraći pregled. U kontekstu tog pristupa, analiza se vrši na tri različite razine: 1 . vid proizvodnje (primjerice, feudalizam ili kapitalizam), 2. režim akumulacije (socio-ekonomski poredak koji je na snazi između dvije strukturalne krize i koji potiče akumulaciju) i 3. institucionalni ili strukturni oblici (monetarni režim, odnos plaće i rada, oblici konkurencije, oblici uključivanja u međunarodni režim, oblici države) (Boyer i Saillard 2002). Oslanjajući se na te temelje, istraživači su najvećim su djelom istraživali fordizam, razdoblje koje obuhvaća oko trideset godina nakon Drugog svjetskog rata, ali i razdoblje koje ga slijedi i u kojem se sada nalazimo: postfordizam. Fordizam je u zapadnim zemljama bio obilježen intenzivnom akumulacijom (Brand i Wissen 2011), stabilnim međunarodnim monetarnim sustavom i slabom izloženošću međunarodnoj konkurenciji, stabilnim radnim odnosima i socijalnom državom. Postfordizam obilježavaju ekstenzivna akumulacija (Brand i Wissen 2011), propast stabilnog međunarodnog monetarnog sustava iz Bretton Woodsa, financijalizacija (u smislu porasta važnosti financijskog sektora), tehnološke promjene te slabljenje socijalne države.

O raskoraku između pristupa régulation i pitanja ekologije djelomično je pisao Lipietz (vidi Whiteside 1996), a nešto eksplicitnije i Raza (1999), koji predlaže uvođenje šestog strukturalnog oblika: “veze prirode i društva”. U nedostatku potpuno razvijenog koncepta koji bi premostio taj jaz, poslužit ćemo se konceptom socio-ekološkog režima koji socio-ekonomska obilježja društvenog sustava povezuje s onim biofizičkim, kao i s uporabom energije i materijala (Sieferle et al. 2006, također Spash i Schandl 2009: 50); to nam omogućava da uočimo golemi porast potrošnje energije i materijala po glavi stanovnika i po zemljopisnom području, kao i emisije $\mathrm{CO}_{2}$ po glavi stanovnika u razdoblju između povijesnog poljoprivrednog režima i onog koji započinje s pojavom industrijske revolucije: industrijskog režima (Krausmann et al. 2008, također Spash i Schandl 2009: 53). Potrošnja energije i materijala u izravnoj je korelaciji s ekonomskim rastom, mjerenim porastom bruto domaćeg proizvoda (BDP). Stoga, iako je teoretski moguće zamisliti ekonomski rast bez pretjeranog iskorištavanja prirodnih resursa, povijesni dokazi, čini se, ne govore u prilog tome.

Kao što nas podsjećaju Brand i Wissen (2011: 25), vezu između ekonomskog rasta i pretjeranog iskorištavanja prirodnih resursa nije lako prekinuti: 
$[\mathrm{P}]$ roizvodnja fosilnih goriva i obrasci potrošnje ( ... duboko su ukorijenjeni u odnosima društvene moći, zdravom razumu i svakodnevnim praksama stanovnika globalnog Sjevera, a sve više i globalnog Juga, baš kao što su ukorijenjeni i u cjelokupnoj orijentaciji na ekonomski rast $\mathrm{i}$ kompetitivnost.

Dodamo li tome problem nejednakosti o kojem piše Domazet, kao i trajno visoke stope nezaposlenosti (mladih) prisutne u nekim zapadnim zemljama od početka takozvane Velike recesije, odnosno od 2007./2008. naovamo, lako bismo mogli zaključiti da je prevladavajući ekonomski sustav doživio neuspjeh. Međutim, ne postoje spremne i gotove institucionalne inovacije neopterećene vrijednosnim sudovima koje bi sustav mogle promijeniti nabolje: postoje samo opcije između kojih moramo birati. Iako njegov teorijski aparat izrijekom ne obuhvaća ekološki sustav, fokus pristupa régulation na povijesno stabilne socio-ekonomske konstelacije navodi nas na zaključak da su moguće brojne varijacije socio-ekonomskog sustava. Kako navodi Jessop (2013: 13):

Pitanje da li potraga za rješenjima ekonomske krize obnavlja prevladavajući režim akumulacije i njegov regulacijski modus, ne ovisi isključivo o objektivnim obilježjima krize i mogućnostima njenog rješavanja unutar ovog okvira. Ono također ovisi o institucionalnim i organizacijskim, kao i kapacitetima učenja društvenih silnica koje nastoje iznaći rješenje krize, kao $i$ ishodu pokušaja definiranja naravi krize, tumačenja njenih raznih objektivnih uzroka, svaljivanja krivice za njen razvoj, te identificiranja najadekvatnijih rješenja.

Kao glavne uzroke opadanja udjela plaća u posljednjih dvadeset i pet godina (koja zajedno pridonose porastu nejednakosti) Stockhammer (2013) navodi financijalizaciju, slabljenje socijalne države i globalizaciju. Štoviše, i sama socio-ekonomska kriza kojoj trenutno svjedočimo uzrokovana je financijalizacijom i povećanjem nejednakosti (Stockhammer 2012). Stockammer (2012: 64) stoga zaključuje da valja:

zagovarati definancijalizaciju. To podrazumijeva smanjivanje financijskog sektora, osnaživanje dionika kao što su radnički sindikati nauštrb dionika u korporativnoj upravi. Nadalje, to bi za cilj imalo nadomještanje logike maksimalnog povećanja profita (ili vrijednosti dioničarskih uloga) u brojnim društvenim sferama demokratski određenim strateškim prioritetima i principima solidarnosti.

Iako to ne izaziva polemike u kontekstu progresivne ekonomske politike koja je $\mathrm{k}$ tomu i demokratski i socio-ekonomski održiva, navod iz Stockhammerovog zaključka koji slijedi pisan je iz perspektive ekonomskog rasta i kao takav ne nailazi na opće odobravanje ekološki osviještenih znanstvenika s područja društvenih znanosti (Stockhammer 2012: 64): "[J]edan od uvjeta za ponovno uspostavljanje održivog režima rasta jest veći porast plaća. Porast plaća mora u najmanju ruku pratiti porast proizvodnje”. Ovaj tip reformističkog strateškog odgovora nastoji riješiti pitanje ekonomske stabilnosti osiguravanjem nesmetanog ekonomskog rasta putem pravednije raspodjele dohodaka unutar ekonomije (progresivno oporezivanje ovdje se nadaje kao očit izbor). No ukoliko nismo u stanju osigurati odvajanje ekonomskog rasta od prekomjernog iskorištavanja Zemljinih resursa i uporabe energije, tada ova strategija sama po sebi ne može predstavljati održivu alternativu.

Radikalno rješenje nudi koncept, kao i stratešku inicijativu (održivog) od-rasta kojemu je cilj smanjiti cjelokupnu količinu materijala i energije koje društvo koristi, budući da se pretpostavlja da se to ne može postići s rastućim BDP-om. Međutim, to nije isto što i težnja za negativnim stopama rasta BDP-a (Kallis 2011: 874). Težiti k održivom od-rastu znači tragati za institucionalnim inovacijama na brojnim problematičnim područjima. 
$[\mathrm{M}]$ ogući prijedlog jest uvođenje globalnih ograničenja na ključne resurse poput nafte i emisije $\mathrm{CO}_{2}$, koje narodi ravnopravno dijele po principu potrošnje po glavi stanovnika ("ograniči i dijeli", Douthwaite 2011) i kojih je s vremenom sve manje. Osim toga, pobornici od-rasta iznose tri dodatna prijedloga kako se nositi s negativnim posljedicama ekonomskih rezova na području zaposlenosti i društvene stabilnosti: podjela rada, jačanje sustava socijalnog osiguranja i alternativni ekonomski prostori koji egzistiraju izvan granica tržišne ekonomije (Latouche 2009). (...) Nadalje, veza između blagostanja i pristupa plaćenom radu u formalnoj ekonomiji može oslabiti uslijed povećanog pristupa nenovčanim dobrima i uslugama. Unutar ove domene postoje brojne društvene inovacije, uključujući urbane vrtove za uzgoj hrane za vlastite potrebe, "banke vremena" u kojima korisnici razmjenjuju usluge na temelju vremena potrebnog za njihovo obavljanje, te projekti zajedničkog stanovanja (eng. co-housing), u kojima sudionici zajednički ulažu nenovčana sredstva (tzv. sweat equity) u obnovu stambenog prostora (Oarlsson 2008; NEF 2009). (van den Bergh i Kallis 2012: 912-913)

Na temelju opisanog okvira mogli bismo zaključiti da se institucionalne inovacije za novu ekonomiju ne bi smjele sastojati od jednostavnih "popravaka” postojećeg ekonomskog sustava, jer im je zadaća mijenjati njegove temelje. Umjesto da promičemo konkretne institucionalne inovacije, predstavili smo neke moguće strategije koje bi drugdje valjalo dodatno elaborirati, imajući na umu socio-ekonomske i ekološke temelje naših društava.

\section{Tomislav Tomašević Grupa 22, Zagreb}

\section{Održivi gradovi: Mi u gradovima koji se moraju mijenjati}

Prvi put u povijesti čovječanstva više ljudi živi u složenim, gusto naseljenim, pretežno nepoljoprivrednim okolišima koje je stvorio čovjek i koje nazivamo gradovima, nego u ruralnim područjima. Tu prekretnicu u povijesti naše vrste dosegli smo 2008. godine (UNFPA 2007). To je još jedan dokaz koji govori u prilog tezama o povijesno neusporedivom utjecaju ljudske vrste na planetu Zemlju, koje u svom tekstu iznosi Domazet, utjecaju koji je neke znanstvenike potaknuo da ovu "geološku" eru nazovu "antropocen”. Možda svjedočimo novoj unutrašnjoj geološkoj podjeli ere antropocena; Burdett i Rode (2010), naime, najavljuju početak "urbanog doba”, u kojem se očekuje da će tri četvrtine svjetskog stanovništva do 2050. živjeti u gradovima. To je vrhunac rastućeg procesa globalne urbanizacije, započetog prije dva stoljeća i neraskidivo povezanog s procesima industrijalizacije, modernizacije i razvoja kapitalizma. Sve je jasnije da, ako se želimo baviti problemom globalne održivosti suvremene civilizacije o kojem Domazet progovara u uvodnom tekstu, moramo uzeti u obzir pitanje održivosti ili neodrživosti grada kao dominantnog oblika ljudskog staništa.

Prije nego istražimo jesu li gradovi u većoj mjeri dio problema globalne održivosti suvremene civilizacije ili njegovog rješenja, valja se pozabaviti ranije otvorenim pitanjem vrijedi li civilizaciju spašavati, ili čak, na koje temeljne sastavnice bi je se najlakše moglo svesti? Na postojeći globalni ekonomski sustav koji širom svijeta proizvodi društvenu i ekološku nepravdu? Na često imperijalističku zapadnjačku kulturu i znanost? Na međunarodni poredak ili zajednicu nacionalnih država koje nisu u stanju upravljati globalnim i dugoročnim prijetnjama čovječanstvu i milijunima drugih vrsta? Enciklopedija humane geografije "civilizaciju” definira kao "proces intelektualnog, duhovnog i estetskog razvoja u kojem ljudi napuštaju 
stanje divljaštva i hijerarhijski napreduju od niskih kultura prema visokoj kulturi” (Warf 2006: 323). U tekstu se dalje navodi da se spomenuta ideja kritizira i kao linearni evolucijski proces koji opravdava dominaciju jedne skupine ljudi nad drugima, ali i kao negativni proces koji ljude udaljava od prirode, pretvarajući time "niske kulture" u idealne civilizacije. U ovome se radu polazi od pretpostavke da globalnu civilizaciju kao globalno društvo doista treba održati, ne zato što bi ona predstavljala najbolji od svih mogućih svjetova koji je sam po sebi vrijedan spašavanja, već stoga što bi odabir neodrživog puta materijalne potrošnje u konačnici mogao dovesti do povratka globalnog društva u manje poželjno stanje. $S$ druge strane, transformacija društvenih struktura s ciljem nadilaženja i materijalnih ograničenja $i$ umnožavanja društvenih nejednakosti mogla bi globalnom društvu omogućiti pomak ${ }^{8}$ prema univerzalnoj ljudskoj emancipaciji. Mišljenja smo da civilizacija doista jest napredovala, unatoč svim svojim nesavršenostima, a u budućnosti bi mogla ili nazadovati ili dalje napredovati, no pritom smatramo da povratak u "tradicionalna", "primitivna" društva ili "niže kulture" ne može biti put ka većoj održivosti okoliša. Potonji koncept nailazi na podršku onih koji vjeruju da su predmoderna društva živjela u skladu s prirodom: u literaturi ta se ideja naziva mitom o "ekološkom plemenitom divljaku" (Redford 1990). Etimološki gledano, "civilizacija” (eng. civilisation) je bliska "gradu” (eng. city), a Bagby "civilizaciju” definira kao "kulturu u kojoj nalazimo gradove” (1959: 162). Prije negoli odgovorimo na pitanje jesu li gradovi problem ili rješenje za ekološku, društvenu i ekonomsku održivost globalne civilizacije, treba riješiti ove konceptualne pretpostavke.

Imamo li na umu ekološke aspekte problema urbane održivosti, pokret za očuvanje okoliša od samog je početka bio skeptičan prema industrijalizaciji i njenom nusproizvodu, urbanizaciji, što je dovelo do još uvijek aktualne rasprave o tome jesu li gradovi problem ili rješenje za održivost globalnog okoliša. Na jednoj strani rasprave nalaze se moderniji pristupi poput "pametnih gradova” (Seisdedos 2012), koji u gradovima - uglavnom utemeljenima na paradigmi eko-učinkovitosti prema kojoj visoka gustoća urbanih formi omogućava učinkovitiji prijevoz, industrijsku proizvodnju i druge urbane sustave potpomognute sofisticiranom tehnologijom i društveno inteligentnim dizajnom - vide rješenje za održivost okoliša. Dakako, nije isto govorimo li, primjerice, o tipičnom američkom ili tipičnom europskom gradu, o urbanom sprawlu (neplaniranom i nekontroliranom širenju urbanog područja; op.prev.) ili kompaktnom gradu. Istina je da gradovi mogu u znatnoj mjeri smanjiti otisak ljudskog staništa, što možemo apstraktno ilustrirati predodžbom jedinstvenog svjetskog grada. Kada bismo trenutnu svjetsku populaciju smjestili u jedan jedini grad, taj bi imao gustoću naseljenosti Pariza i zauzimao površinu približno jednaku površini Finske. ${ }^{9}$ Nažalost, stanišni otisak gradova sam po sebi nije jednak njihovom ukupnom ekološkom otisku: naime, materijali i energija koje gradovi troše iziskuju mnogo veće zemljišne površine od područja na kojima su izgrađeni. Ideja eko-učinkovitih gradova sugerira ne samo da gradovi unapređuju globalnu održivost, već da veliki gradovi mogu povećati učinkovitost po glavi stanovnika i kao takvi bi globalnoj održivosti mogli doprinijeti u većoj mjeri nego manji gradovi.

Međutim, nedavna studija (Oliveira et al. 2014) pokazuje da, unatoč ekonomiji razmjera koja povećava učinkovitost, veliki gradovi imaju proporcionalno veći ugljični otisak od malih gradova. Kako je moguće da unatoč većoj učinkovitosti transportnog i drugih sustava veliki

\footnotetext{
${ }^{8}$ Odlučio sam se za pojam "pomicanje" (eng. advance) a ne "napredovanje" (eng. progress), jer je potonji opterećen simboličkim značenjima i povezan $s$ teorijom modernizacije i zapadnjačkim poimanjem napretka kao linearnog determinističkog razvoja koji nazadna društva moraju proći.

${ }^{9}$ Prema podacima važećim u trenutku pisanja, naša računica glasi ovako: ukupan broj svjetskog stanovništva (7 170000000 ljudi) podijeljen s gustoćom naseljenosti Pariza (21 289 stanovnika/km2); površina svjetskog grada $(336793 \mathrm{~km} 2)$ približno je jednaka površini Finske (337 030 km2).
} 
gradovi i dalje imaju veću emisiju $\mathrm{CO}_{2}$ po stanovniku nego mali gradovi? Oni jednostavno više proizvode (u konačnici u materijalnom smislu), što znači da njihovi stanovnici ostvaruju veći dohodak per capita te više i troše. To pokazuje da će fokusiranje isključivo na učinkovitost gradova i zanemarivanje dostatnosti ili potrošnje materijala i energije u gradovima, u konačnici biti nedostatno u smislu postizanja urbane održivosti. Gradovi teže ekonomskom rastu pod svaku cijenu, što nužno dovodi do porasta potrošnje; stoga bez restrukturiranja s ciljem od-rasta ili anti-rasta, učinkovitost i tehnološke inovacije neće biti dovoljne za postizanje održivosti urbanog okoliša.

$\mathrm{Na}$ drugoj strani rasprave nalaze se više postmodernistički okolišni pristupi gradovima, koji u njima vide problem za održivost okoliša budući da neizbježno vode u konzumerizam, otuđenje od prirode i društveni atomizam. Namjesto gradova, ti borci za okoliš zalažu se za eko-sela u kojima bi se zadovoljavale jedino "prave" materijalne ljudske potrebe, i to niskom tehnologijom u vidu primitivne zemljoradnje i obrta, što bi dovelo do obnavljanja osjećaja zajedništva (Kasper 2008). Taj pristup zagovara i pokret "Gradovi u tranziciji” (eng. Transition Towns) na čelu s Robom Hopkinsom (2008), utemeljiteljem prvog eko-sela u Irskoj. Usmjeren uglavnom na manje gradove, pokret "Gradovi u tranziciji" za cilj ima smanjenje ugljičnog otiska, uporabe fosilnih goriva i osjetljivosti na promjene u globalnim financijskim tokovima kroz lokalizaciju ekonomije i izgradnju zajednice. Takvi manji i tradicionalniji fizički oblici ljudskih naselja ne bi uživali dobrobiti ekonomije razmjera, niti prakticirali sofisticiranu podjelu rada, što znači da bi bili manje učinkoviti, ali više (samo)održivi, zadovoljavajući jedino osnovne materijalne ljudske potrebe. Međutim, postavlja se pitanje može li svijet koji će uskoro nastanjivati devet milijardi ljudi sebi priuštiti takvu deindustrijalizaciju, demodernizaciju i dekoordinaciju, ako želi zadovoljiti čak i najosnovnije potrebe svih tih ljudi.

Pristup eko-sela i eko-gradova u skladu je sa specifičnim ekološkim okvirom zvanim "malo je lijepo" (Schumacher 1993). Međutim, malo ponekad nije i tehnološki optimalno, primjerice, u domeni pretvorbe energije koju Domazet u uvodnom tekstu ističe kao ključnu sastavnicu razvojnog projekta. Primjer energetske učinkovitosti elektrana na biomasu pokazuje da veće elektrane mogu u električnu energiju pretvoriti znatno veći postotak termalne energije iz biomase nego manje elektrane (Austin 2008). Ako se, kao što tvrdi Domazet, "moramo promijeniti", tada se u ovome radu tvrdi da "moramo mijenjati gradove" koristeći kombinaciju spomenutih pristupa, odnosno hvatajući se u koštac i s urbanom eko-učinkovitošću i s eko-dostatnošću. Gradovi bi mogli biti dio rješenja za održivost globalnog okoliša, no samo ako se društvene strukture i upravljački mehanizmi u njima promijene do te mjere da su u stanju zaustaviti porast besmislene potrošnje, te istodobno povećati korištenje učinkovitih resursa. Koncept zajedničkog dobra mogao bi popuniti tu prazninu budući da bi istodobno mogao zahvatiti i u problematiku dostatnosti i u problematiku učinkovitosti, unoseći društvenu organizaciju eko-sela u urbani fizički oblik na široj razini. Primjerice, zajednički urbani vrtovi učinkovitije koriste prirodne resurse budući da namjesto pojedinaca s vlastitim, privatnim parcelama, imamo zajednicu koja koristi jedan komad zemljišta; zajednička proizvodnja i potrošnja stvara društveni kapital i osjećaj zajedništva; postoji pravedan pristup proizvedenoj hrani ne samo unutar pojedine urbane zajednice, već i kroz trgovinu i preraspodjelu s drugim zajedničkim vrtovima unutar istog grada.

Društveni aspekt urbanizacije povezan je s raspravom o procesu modernizacije koji putem tehnoloških i znanstvenih napredaka ruralno i tradicionalno društvo transformira u urbano i moderno. Jedan dio pokreta za očuvanje okoliša i drugih društvenih pokreta modernizaciju vidi kao negativan proces budući da tradicionalnu ruralnu kulturu zajednice i suradnje pretvara u modernističku kulturu individualizma i nadmetanja. Drugi dio modernizaciju 
smatra pozitivnim društvenim procesom koji će dokinuti tradicionalne zajednice i društvene odnose utemeljene na srodstvu, koje se uglavnom povezivalo s opresivnim društvenim oblicima kao što je patrijarhat. Već smo istaknuli da se nećemo zalagati za povratak tradicionalnom predmodernom društvu kao arhetipu ekološke održivosti, budući da bi takva regresija mogla značiti više opresije i manje slobode identiteta. Kako onda pomiriti osobne slobode i identitete s jedne strane, i kolektivnu skrb i osjećaj zajedništva s druge? Odgovor koji na to pitanje nudi Iris Marion Young (1990) leži u gradu, u urbanom društvenom životu. Za Young, gradovi predstavljaju savršeni model u kojem se spajaju raznolikost i zajedništvo, koji onemogućava uskogrudnost, i u kojem različiti identiteti mogu supostojati održavajući društveni kapital, solidarnost i toleranciju. Male zajednice vrše društveni moralni pritisak na pojedinca da se uklopi, dok veliki gradovi istovremeno nude i anonimnost kao preduvjet individualne slobode i izravno iskustvo pripadanja većoj zajednici ili zajednicama.

Ekonomski aspekt urbanizacije i urbane održivosti neraskidivo je povezan s razvojem kapitalizma. Domazet smatra da tehnološko rješenje nije odgovor na pitanje održivosti okoliša, no "prostorno rješenje" ili globalna urbanizacija ipak jest riješila problem održivosti kapitalističkog oblika razvojnog projekta (Harvey 2001). Njegova globalna urbanizacija stvara prostorne nejednakosti na globalnoj razini i ekonomske (a stoga i društvene i političke) nejednakosti u gradovima (Smith 2010). Neoliberalna urbanizacija u razvijenom kapitalizmu istovremeno stvara društvene nejednakosti i crpi sve veće količine prostora/resursa radi održavanja kapitalističkog sustava. To znači da neoliberalna urbanizacija daje jedan od najvećih doprinosa kombinaciji koju spominje Domazet, i koja vodi u potpuni slom civilizacije. Promjena načina na koji se gradovi reproduciraju stoga je povezana s promjenama urbanih ekonomskih sustava, odnosno društvenih struktura proizvodnje, raspodjele i potrošnje. Ako ekonomija slobodnog tržišta stvara izopačene ishode distribucije, ostaje pitanje kako onda osigurati učinkovito korištenje prirodnih resursa. Državni mehanizmi ekonomske vlasti povijesno su se pokazali odviše sporima i neučinkovitima te se stoga pravo rješenje možda krije u upravljanju zajedničkim dobrima i ekonomskoj demokratizaciji. Kako bi se osiguralo učinkovito upravljanje resursima, nakon društvenih inovacija trebale bi doći one tehnološke: naime, ranije spomenuta studija (Oliveira et al. 2014) pokazuje da veliki gradovi stvaraju više tehnoloških inovacija (mjerenih kao patenti po glavi stanovnika) u odnosu na manje gradove, vjerojatno zbog visokog stupnja dinamike i razmjene velikog broja ljudi i njihovih ideja. Empirijski podaci Elinor Ostrom (1990) nude brojne primjere uspješnog zajedničkog upravljanja prirodnim i drugim resursima; međutim, te zajednice nikada ne prelaze nekoliko tisuća ljudi. Ako će održivi grad ujedno biti “zajednički grad”, to znači desetke tisuća upravljačkih sustava utemeljenih na zajedničkim dobrima, koji zajedno čine vrlo složenu opću strukturu vlasti koja im omogućava međusobnu koordinaciju i pregovore. Međutim, čini se da je klimatska kriza na putu, a teorija sustava pokazuje da se složeni prilagodljivi sustavi mogu prilagoditi svojim promjenjivim okolišima kako bi se održali. 


\title{
Jeremy F. Walton
}

\section{Sveučilište Georg August, Göttingen}

\author{
Prema kritici političke ekonomije klimatskih promjena onkraj \\ opozicije priroda/kultura: razmatranja jednog antropologa
}

Filozofi su samo, na različite načine, tumačili svijet. Cilj je, međutim, promijeniti ga. (Karl Marx, Theses on Feuerbach, 1998: 571)

Želite spasiti slonove u parkovima Kenije tako što ćete im dati da pasu odvojeno od krava? Odlično, ali kako ćete doznati mišljenje pripadnika naroda Masai koji su odsječeni od krava, i krava kojima su oduzeti slonovi koji za njih krče žbunje, i slonova koji su odvojeni i od naroda Masai i od krava? (Bruno Latour 2004: 170)

Iz određenog gledišta antropologija se može doimati kao neobična disciplinarna platforma za odašiljanje kritika na račun globalne političke ekonomije klimatskih promjena. Prema poznatoj taksonomiji društvenih znanosti, antropologiju se redovito prikazuje kao ogrezlu u partikularizmu i zaokupljenu idiografskim opisima, a ne nomotetičkim objašnjenjima (usp. Wallerstein et al. 1996). Međutim, u ovom kratkom eseju tvrdim da antropologiji pripada ključna, štoviše središnja uloga u tumačenju dilema povezanih s klimatskim promjenama i osmišljavanju strategija kojima će se ublažiti njihove negativne posljedice. Potencijalni doprinos antropologije raspravi o izazovima koje pred nas postavljaju klimatske promjene proizlazi iz njenih konceptualnih temelja: više od bilo koje druge znanstvene discipline, antropologija se intenzivno i kontinuirano hrva s problematičnom vezom između "prirode" i "kulture". Posljednjih desetljeća antropolozi su raniju, esencijalističku distinkciju između "prirode" i "kulture" zamijenili iznijansiranim, na praksi utemeljenim holizmom koji "prirodu” i "kulturu” poima kao uzajamne koncepte koji nužno posreduju i uvjetuju jedan drugoga. Ta revizionistička perspektiva u sebi zacijelo sadrži po(r)uke od ključne važnosti za raspravu o klimatskim promjenama. Namjesto percepcije klimatskih promjena kao niza "kulturnih" utjecaja na "prirodu" (stajalište koje na problematičan način razdvaja ljudsko djelovanje od same "prirode") zalažem se za novi narativ klimatskih promjena, koji će političku ekonomiju neoliberalnog kapitalizma pretvoriti u glavni predmet kritike. $\mathrm{Na}$ taj se način odazivam na poziv Mladena Domazeta da "pozornost čovječanstva [skrenemo] na procese koji se odvijaju na ne-ljudskim razinama ... na emancipirajući način kako bismo primijenili od-rast na civilizaciju bez uništavanja njenih dosadašnjih (tehnoloških i društvenih) postignuća” (2014: 14).

Antropologija ranog dvadesetog stoljeća, naročito ona kakvu su prakticirali i zagovarali profesor sa Sveučilišta u Kolumbiji Franz Boas i njegovi studenti u Sjevernoj Americi, svoj je disciplinarni legitimitet izgradila na granici između sfera prirode i kulture (Boas 1989). Za Boasa i njegove sljedbenike, kultura, kao prostor jedinstveno ljudskih obilježja i ponašanja, počinje upravo tamo gdje priroda završava. Kao što je pokazao povjesničar antropologije George Stocking (1982), Boasova rana "kulturna" antropologija odigrala je presudnu ulogu u nadilaženju evolucijskih i rasističkih predrasuda antropologije devetnaestog stoljeća. Nakon Boasa, došlo je do temeljnog razilaženja između biološke antropologije (ukorijenjena u proučavanju ljudskih bića kao prirodnih organizama i još uvijek zaokupljena pitanjima evolucije) i kulturne antropologije (fokusirana na ljudska bića kao primarno društvene i kulturne čimbenike). Sredinom dvadesetog stoljeća američka je antropologija i dalje bila ukorijenjena u konceptu kulture, o čemu svjedoči opus Clifforda Geertza (1977). S druge strane 
Atlantskog oceana britanski etnolozi, nadahnuti funkcionalističkom durkheimovskom sociologijom, iscrtavali su podjednako stroge granice između prirode i društvene strukture (npr. Radcliffe-Brown 1965).

Unutar antropologije, strogi dualizmi prirode/kulture i prirode/društva počinju slabjeti tek s pojavom strukturalizma i kopernikanskim obratom u antropološkoj misli koji je potaknut radom Claudea Lévi-Straussa. Poznata je Lévi-Straussova inauguracija kritike razlikovanja znanstvenog i drugih oblika ljudskog mišljenja: "Znanstvenik nikada ne dijalogizira samo s prirodom, već prije s osobitom vezom između prirode i kulture koju je moguće definirati u kontekstu specifičnog razdoblja i civilizacije u kojoj sam znanstvenik djeluje, te materijalnih sredstava koja su mu na raspolaganju" (1966: 19). Iz pozicije strukturalizma (a neizbježno i poststrukturalizma), priroda više nije apsolutni Drugi kulture; umjesto toga, sama opozicija priroda/kultura dio je šireg, holističkog procesa proizvodnje značenja. Odavde do argumenata Bruna Latoura (1993) kratak je put; njegov model studija znanosti i tehnologije (eng. science and technology studies, skrać. STS) odbacuje ne samo razlikovanje kulture i prirode, već i ljudi i ne-ljudi, te subjekata i objekata.

Budući da smo zakoračili na potencijalno tanak konceptualni i politički led, red je da izdamo upozorenje. Ovu kratku i djelomičnu povijest antropoloških nagađanja o dihotomiji prirode i kulture tekstu sam dodao kako bih razotkrio neke od zamki teoretiziranja o klimatskim promjenama. Konkretno, dvije zamke - jedna Scila i jedna Haribda - prijete našoj analizi i političkoj ambiciji: na jednoj strani anakronistički, besramni esencijalizam koji reificira i prirodu i kulturu, uspostavljajući pritom jedinstvenu privilegiranu poziciju znanstvenog razuma; na drugoj strani, karikirani postmodernistički relativizam koji destabilizira osnove svog znanja bez razlike, i znanstvenog i drugog, osujećujući time svako političko djelovanje. Prva zamka, simplicistički esencijalizam, ima pogubne posljedice mimo dvostruke reifikacije prirode i kulture. Ono što je još važnije u kontekstu ove rasprave jest činjenica da opreka priroda/kultura nadzire vatrozid između "prirodnih" i "društvenih" znanosti, što rezultira time da argumenti svake od dvaju skupina znanstvenih disciplina za onu drugu postaju nevažeći i neučinkoviti. Kao što Domazet uvjerljivo tvrdi, takav oblik akademske uskogrudnosti ima pogubne posljedice po priznavanje činjenice da "naša vrsta sudjeluje u procesima na bitno različitim razinama koje su u pravilu oblasti odvojenih diskurzivnih disciplina” (2014: 7). Jedino nadilaženjem strogog razgraničenja između "prirodnih" i "društvenih" znanosti možemo se nadati da ćemo "pronaći glas koji dopire iz perspektive opkoračenja tih različitih razina” (ibid.). Ta "perspektiva opkoračenja” ključna je i za izbjegavanje druge zamke: nihilističkog relativizma. Integrativna "perspektiva opkoračenja”, koju zagovara Domazet, nužno nas odvodi onkraj Latourove dekonstrukcije znanstvenog znanja kojeg se često proziva kao sukrivca skeptika prema klimatskim promjenama i drugih politički reakcionarnih čimbenika (Sokal 1996; vidi također Demeritt 2006). U ostatku ovog eseja cilj mi je pridonijeti upravo toj vrsti "perspektive opkoračenja" i borbi protiv epistemološkog nihilizma povezanog s klimatskim promjenama, destabiliziranjem opreke priroda/kultura uz pomoć trećeg termina (koji, treba reći, Domazet također propitkuje): neoliberalnog kapitalizma.

Kapitalizam iziskuje da ga pomno i kritički propitkujemo upravo zato što je, poput političke ekonomije, bezbrižno ravnodušan prema opoziciji priroda/kultura. Kao što je davnih dana izraženo u poznatoj metafori Marxa i Engelsa, unutar režima kapitalističke komodifikacije "sve što je čvrsto i postojano pretvara se u dim" (1948: 16), bez obzira na to je li riječ o "prirodnim" ili "kulturnim" tvarima. Antropolog političke ekologije Arturo Escobar nedavno je istaknuo hitnost upisanu u ovu temeljnu ideju marksizma: "Priroda se više ne definira i ne tretira kao izvanjska domena koju je moguće iskorištavati. Putem novog procesa 
kapitalizacije (... ) prethodno 'nekapitalizirani' aspekti društva i prirode postaju sastavni dijelovi kapitala” (1995: 199). Na začudan način, kapitalizam pragmatički uspijeva tamo gdje su društvene znanosti doživjele teorijski neuspjeh: on razrješava opoziciju priroda/kultura pohlepno apsorbirajući i komodificirajući i "prirodu” i "kulturu”.

Koje su političke posljedice izgradnje kritike klimatskih promjena na propitkivanju neoliberalnog kapitalizma, a ne na granici prirode i kulture? Najneposrednije, ovaj fokus na kapitalizam vraća pokret za zaštitu okoliša i zeleni aktivizam u središte interesa, i to kao predanost društvenoj pravednosti, a ne "tek prirodne" orijentacije (usp. Butler 1997). Drugim riječima, kritika klimatskih promjena u jednakoj se mjeri tiče ljudskih subjekata i neegalitarnih odnosa koje održavaju među sobom, kao i "prirodnog” svijeta. Vrijedi i suprotno: društvena pravednost nije samo pitanje ljudske nejednakosti. U razdoblju neoliberalnog kapitalizma, obveza prema društvenoj pravdi nužno nadilazi problematičnu podjelu na prirodni i kulturni, ljudski i ne-ljudski svijet.

No čak i dok se zalažemo za ponovnu procjenu odnosa između kapitalizma i klimatskih promjena, moramo biti oprezni kako jednu konkretizaciju ne bismo zamijenili drugom. Kapitalizam, naročito u njegovoj neoliberalnoj inačici, nije esencija ništa više nego su to "priroda" ili "kultura”. Posljedično, otpor učincima neoliberalnog kapitalizma (klimatskim i/ ili inim) također mora nužno biti mnogolik i izmješten iz središta. Kao što nas podsjećaju Michael Hardt i Antonio Negri (2001), globalno “mnoštvo” dvadeset prvog stoljeća nije isto što i proletarijat devetnaestog stoljeća. Dakako, to ne znači da nam u borbi protiv klimatskih promjena nije hitno potrebna globalna politička reorijentacija, čvrsto utemeljena na "razmišljanju za dvadeset drugo stoljeće”, kakvo strastveno zagovara Domazet. Jednostavno treba priznati da spomenuti proces otpora i reorijentacije nije i ne može biti identičan u svim svojim specifičnim kontekstima. No to nije razlog za pesimizam. Kao što antropologinja i borac za okoliš Anna Tsing (2005) uvjerljivo pokazuje, "trenje” među kontekstima i razinama političkog aktivizma u doba guste, višedimenzionalne međupovezanosti koju nazivamo globalizacijom je neizbježno. Umjesto da očajava zbog tog trenja protiv kojega ne može ništa, globalni pokret protiv klimatskih promjena mora ga prepoznati i iz njega crpiti snagu.

Zaključno, želio bih se kratko osvrnuti na dva citata (Marxov i Latourov) kojima sam uokvirio ovaj esej. Zajedno, oni djeluju kao smjernice za koordinaciju mojih argumenata i težnji. Po uzoru na Marxa, tog paradigmatskog aktivističkog intelektualca, valja istaknuti da je znanstvena spekulacija razdvojena od političkog djelovanja jedva nešto bolja od kola bez konja. Tumačiti svijet klimatskih promjena, a ne mijenjati ga, znači perpetuirati društvene i ekološke nepravde ovoga svijeta. Latour nam, pak, nudi po(r)uku upozorenja. Čak i dok nastojimo povezati vlastitu interpretaciju klimatskih promjena s pragmatičkim političkim djelovanjem, moramo voditi računa o trenju koje će naš politički projekt neizbježno izazvati i uključivati. Nisu sve stečene obaveze međusobno uskladive: interese slonova, krava i pripadnika naroda Masai ne možemo tretirati kao međusobno posve razmjerne. Pomake na globalnoj razini borba protiv klimatskih promjena može postići jedino uvažavanjem i hvatanjem $\mathrm{u}$ koštac s problemom brojnih vrsta trenja. Upravo u tom ključnom trenutku antropologija, sa svojim kontinuiranim fokusom na pojedinosti konteksta, može preuzeti vlastitu ulogu u borbi protiv klimatskih promjena. Dok su klimatolozi i politički ekonomisti ključni za iscrtavanje obrisa i predviđanje posljedica klimatskih promjena na globalnoj razini, antropolozi su u idealnoj poziciji da slijede i uklanjaju trzavice do kojih će projekt obrtanja klimatskih promjena nužno dovesti.

Ovim kratkim razmatranjem pokušao sam dati malen doprinos ovom projektu nadvladavanja trenja istraživanjem antropološkog naslijeđa opozicije priroda/kultura i njenog odnosa 
prema debati o klimatskim promjenama. Nadahnut Domazetovim esejom, ustvrdio sam da su odbacivanje esencijalističke opreke priroda/kultura te popratni fokus na pitanja neoliberalnog kapitalizma i društvene pravde ključni za unaprjeđivanje političke borbe protiv klimatskih promjena. Nadam se da su ove interpretacije i same izazvale nešto trenja: na koncu, trenje je izvor topline i energije te poticaj za djelovanje. A mogućnost ove vrste djelovanja (promijeniti svijet klimatskih promjena) ono je što ujedinjuje naše raznolike intervencije unutar ovog foruma i, nadajmo se, foruma koji dolaze.

\section{Karin Doolan Grupa 22, Zagreb}

\section{Promjena klime, društvena nepravda i patologija života u postindustrijskom kapitalizmu}

Ton Domazetovog teksta prigodno je hitan. “Živimo u izvanrednim vremenima”, piše on, obilježenim nezadovoljivom i štetnom težnjom kapitalizma za rastom i s njom povezanim promjenama globalnog okoliša i rastućim društvenim nejednakostima. Domazet se poziva na niz stručnih izvora, upozoravajući nas da je nada u tehnološko otkriće koje će nas izbaviti iz klimatskih poteškoća naivna, te predlažući da namjesto toga prigrlimo projekt održivog od-rasta. Cilj mojega odgovora na Domazetov tekst (2014) je trostruki: pobliže sagledati teme predstavljene u njegovom radu kao i aspekte društvene nepravde promjene klime te nadovezati se na njegov rad proširivanjem njegove kritike kapitalizma iz perspektive literature o afektivnim posljedicama života u potrošačkom društvu s jedne, te kratkim osvrtom na osobnu pristranost i sklonost statusu quo u smislu ekološkog djelovanja, s druge strane. $\mathrm{Na}$ taj način želim dati vlastiti doprinos onome što vidim kao Domazetov kritički projekt procjenjivanja "utvrđenog načina organizacije društva" u odnosu na "druge mogućnosti, mogućnosti za koje se smatra da nude bolje izglede za olakšavanje čovjekove borbe za egzistenciju" (Marcuse 1991 [1964]: 42) (iako bi, u kontekstu klimatskih promjena, Marcuseovu frazu "čovjekova borba za egzistenciju" bilo primjereno zamijeniti izrazom "borba planeta za egzistenciju”).

Barker, Scrieciu i Taylor (2008) klimatske promjene opisuju kao "suštinski pristrane i stoga nepravedne", jer "sistematski i nemilosrdno" pogađaju "ranjive, siromašne i ekstremno siromašne” (2008: 318). O dimenziji društvene pravednosti promjene klime u stručnoj se literaturi raspravlja kao o nadnacionalnom i nacionalnom, među- i unutargeneracijskom problemu. U nedavno objavljenoj studiji Preston et al. (2014) zaključuju da se teorijska literatura o klimatskoj pravednosti dosad najčešće fokusirala na nejednaku raspodjelu odgovornosti za emisiju ugljika među državama, odnosno između Sjevera i Juga ili postindustrijskih i zemalja u razvoju. Iako autori priznaju da je važno skrenuti pozornost na nadnacionalnu dimenziju klimatske pravednosti, također detaljno objašnjavaju njenu nacionalnu dimenziju: ugrožene skupine najmanje pridonose uzrocima klimatskih promjena, a ipak će se te promjene upravo na njih najviše negativno odraziti; od svog dohotka najviše plaćaju implementaciju određenih strategija, a ipak od njih imaju najmanje koristi; također imaju manju mogućnost sudjelovati u donošenju odluka o spomenutim strategijama. Prema Prestonu et al. (2014), ugrožene skupine uključuju starije osobe, osobe s niskim primanjima te podstanare (potonja se skupina preklapa sa skupinom osoba s niskim primanjima). Služeći se primje- 
rom poplava, autori pokazuju da oporavljanje od posljedica poplave može biti teže ljudima koji žive u siromaštvu, zbog nedovoljnog ili nepostojećeg osiguranja, troškova privremenog smještaja, troškova prijevoza uzrokovanih preseljenjem i smanjenim pristupom kreditima. Oni zahtijevaju da nacionalna politika povezana s klimatskim promjenama vodi više računa o društvenim nejednakostima i pokazuje zabrinutost, primjerice, za posljedice na rizicima utemeljenog tržišnog pristupa osiguranju od poplava (premije osiguranja proporcionalne su razini rizika pojedinog kućanstva), koji je u opreci s pristupom utemeljenim na solidarnosti (manje rizični pomažu visoko rizične). Nedavne katastrofalne poplave u Bosni i Hercegovini, Hrvatskoj i Srbiji (svibanj 2014.) zorno pokazuju neposrednu važnost takvog načina razmišljanja.

Važno povezano pitanje tiče se međupovezanosti ekonomskog rasta, okoliša i društvene pravednosti. Kao što ističe Muraca (2012), postoji podjela na one koji u ekonomskom rastu vide preduvjet za pravednost u raspodjeli i brane njegov utjecaj na okoliš, i one koji u njemu vide prijetnju pravednosti i okolišu. Za prvu skupinu, ekonomski rast povećava ukupnu količinu dobara za raspodjelu što, pak, poboljšava životni standard u cjelini, potiče društvenu mobilnosti i povećava vladine prihode za socijalne službe, što unapređuje cjelokupni sustav socijalne pomoći. Prema tom argumentu, kontinuirani rast nužan je za zapošljavanje i stimulira ulaganje u tehnologije za rješavanje problema okoliša. Domazet (2014) o tome piše kao o "imperativ[u] rasta zaodjenut[om] u obećanje emancipacije", nazivajući kapitalistički imperativ rasta štetnim mehanizmom "koji se hrani rastućim nejednakostima”.

Muracina (2012) kritika od-rasta usmjerena protiv tvrdnji onih koji zagovaraju rast je uvjerljiva: "efekt kapanja nadolje" (eng. trickle-down effect) je neodrživ. Bez preraspodjele, rast vodi u povećanje jaza između bogatih i siromašnih, a postoji i snažna korelacija između rasta BDP-a i uništavanja prirodnog okoliša, uključujući rastuću potrebu za novim resursima koja vodi u geopolitičke oblike dominacije kao što je proizvodnja biomase za globalni Sjever ili neokolonijalno zagađenje vode i otimanje zemlje. Muraca (2012) dalje dovodi u pitanje imperativ rasta, ne samo iz perspektive pravednosti raspodjele i okoliša već i kroz povezanost $s$ našim afektivnim ja. Autorica ističe da postoji negativna korelacija između BDP-a po glavi stanovnika i subjektivnog doživljaja sreće.

O afektivnim dimenzijama života u kapitalizmu pisali su mnogi autori. Ono što je svima zajedničko jest dijagnoza kasnog kapitalizma i potrošačke kulture kao pogubnih za blagostanje. Štetimo planeti potrošnjom koja šteti nama i mimo argumenta društvene pravednosti Martinez-Aliera, koji tvrdi da pretjerana potrošnja bogatih i pripadnika srednje klase "nije samo prijetnja drugim vrstama i budućim generacijama ljudi (...) ona u sadašnjem trenutku siromašne lišava njihovog pravednog udjela u resursima i okolišnom prostoru” (2012: 62). Fromm (1956) koristi koncept "otuđenja" kako bi opisao društveni karakter zapadnjačke "moderne osobnosti”, čovjeka otuđenog od samoga sebe, koji stječe jedino kako bi imao, i kojemu je beskorisno posjedovanje izvor zadovoljstva. Za ideologiju kasnog kapitalizma Salecl navodi da povećava tjeskobu ljudi svojim inzistiranjem na samoprobitačnosti i samoispunjenju, zaključujući da "kako se čini, slobodni konzumenti na koncu konzumiraju sami sebe" (2008: 2340). A prema Illouz, potrošnja se "gotovo isključivo bazira na ideologiji osobne dobrobiti i samozadovoljstva (...) tržište potiče potrošačke izbore koji proizlaze iz kultiviranja hiper-individualističkog identiteta” (2009: 386). Drugim riječima, osjećaj osobne vrijednosti u kapitalizmu kultivira se unutar kategorije individualnog, a ne putem solidarnosti, empatije i prepoznavanja međuovisnosti koja prema Prestonu et al. "leži u središtu kozmopolitskih poimanja klimatske pravednosti” (2014:21).

Čini se da se Domazet nada racionalnom odgovoru na problem klimatskih promjena: poziva nas da napravimo "temeljiti zaokret prema održivosti oslanjajući se na naše kolektiv- 
no znanje”, tvrdeći da oslanjajući se "na opsežno znanje o prirodnim i društveno povijesnim procesima, [možemo] postići da globalna populacija ima koristi od ranije lokaliziranih alternativa". Salecl se, pak, fokusira na emocionalne reakcije na zabrinjavajuće ekološke probleme: "ponašamo se kao da se ništa zapravo ne treba promijeniti" (2012: 2280). Pišući iz perspektive socijalne psihologije, autori(ce) kao što su Johnson i Levin (2009) upozoravaju na to da nas oblikuju razne vrste pristranosti koje djeluju protivno racionalnim reakcijama na klimatske promjene. Osjetilna pristranost tjera nas da izbjegavamo reakcije na prijetnje koje se javljaju izvan granica našeg izravnog iskustva: "Mehanizam mozga ne reagira u potpunosti na nešto sve dok to ne registriramo na tjelesnoj bazi” (Johnson i Levin 2009: 1595). Psihološke pristranosti uključuju pozitivne iluzije (pretjerano pouzdanje povezano s vlastitom podložnosti riziku), kognitivnu disonancu (prilagođavanje proturječnih informacija vlastitim uvjerenjima), temeljnu pogrešku atribucije (pripisivanje vlastitog ponašanja ograničenjima situacije), teoriju očekivanog izbora ("riskiramo time što ne radimo ništa, u nadi da stvari neće ispasti baš tako loše”), te međugrupnu i unutargrupnu pristranost (svaljivanje krivice za uzroke i posljedice klimatskih promjena na druge) (ibid.: 1598). Kako primjećuju autori, svi navedeni oblici pristranosti navode ljude da umanjuju opasnost promjene okoliša i vlastitog udjela u njoj. Uz pristranosti na individualnoj bazi, Johnson i Levin (2009) ukazuju na to da i organizacijska i politička pristranost osujećuju djelovanje usmjereno na očuvanje okoliša. Organizacije opisuju kao birokratski inertne, obilježene postojećim interesima, borbama oko budžeta i nadmetanjem za napredovanjima: to sve rezultira fokusom na prošlost i sadašnjost, umjesto na budućnost okoliša. O pitanju političke pristranosti, autori navode sljedeće: "Sve dok je prijetnja udaljena barem četiri godine ili se krivnja za nju može svaliti na vanjske uzroke ili suprotstavljene političke stranke, prednost će se davati drugim problemima” (ibid.: 1599). Prema Johnsonu i Levinu, tvorci politika i borci za okoliš trebali bi premjestiti fokus s preciznih detalja klimatskih promjena na naše reakcije na njih. U ponešto pesimističnom tonu, autori zaključuju da je "radikalna promjena moguća tek nakon što ljudi - uslijed dovoljnog broja katastrofa ili dovoljno velikih katastrofa - u dovoljnoj mjeri postanu svjesni opasnosti" (ibid.: 1601). Ovdje je, međutim, (uglavnom) riječ o analizi reakcija na klimatske promjene na razini pojedinaca, što ne nudi dostatno objašnjenje za još uvijek nisku razinu djelovanja protiv klimatskih promjena. Na makrorazini, Krugman (2014), primjerice, piše da je teško djelovati protiv klimatske promjene u političko-ekonomskom kontekstu koji se opire intervenciji vlade ("razmislite o globalnom zatopljenju iz pozicije nekoga tko je odrastajući shvaćao Ayn Rand ozbiljno i vjerovao da se uvijek treba voditi za vlastitim interesima, te da vlada uvijek predstavlja problem, nikada rješenje”) i neprijateljski je nastrojen prema znanosti.

U ovom odgovoru naglasak je na sljedećim tvrdnjama: promjena klime problem je društvene pravednosti; lažne potrebe koje stvara naše potrošačko društvo, kao i iskrivljen kapitalistički program kojemu je cilj natjerati nas da više trošimo i više se nadmećemo, pridonose propadanju planeta; pristranosti, postojeći interesi, ideologija i anti-intelektualizam osujećuju djelovanje na planu klimatskih promjena. Željela bih podržati Domazetov poziv na projekt održivog od-razvoja, u duhu "nepristranog i demokratskog prijelaza na manje ekonomije s manje proizvodnje i potrošnje” o kojem pišu Boillat, Gerber i Funes-Monzote (2012: 600). "Ključ je u smanjivanju protoka energije i materijala te istovremenom zadovoljavanju temeljnih i rastućih ljudskih potreba kao što su potreba za hranom, zdravstvenom zaštitom, obrazovanjem i stanovanjem”. Na koncu, već svjedočimo "katastrofama u neposrednoj blizini”. 


\section{Mislav Žitko \\ Filozofski fakultet, Zagreb}

\section{Nova planetarna vulgata: slučaj krize okoliša}

Proteklih je godina, a možda i desetljeća, pitanje neumjerenosti postalo omiljena meta političkih skupina i aktivista civilnog društva smještenih na različitim dijelovima ljevičarskoliberalnog spektra. Neumjerena eksploatacija prirodnih resursa, neumjereni konzumerizam, neumjereni menadžerski bonusi, neumjerena nejednakost i drugi oblici društveno nedoličnog ponašanja često izazivaju pomutnju u javnim raspravama, a ipak je dosad relativno malo napora bilo usmjerno na pronalaženje odgovora na pitanje predstavlja li ta neumjerenost devijaciju u djelovanju suvremenog kapitalizma ili njegov sastavni dio. U ovom kratkom odgovoru na Domazetov tekst (u ovom broju) koji si za cilj zadaje postavljanje temelja "za holističko poimanje ekonomskih nada i geofizičkih pokretača u pozadini tema zelene ekonomije i od-rasta”, ostavljam po strani golemo područje slaganja kako bih se usredotočio na one točke za koje držim da su prijeporne ili da ih treba drugačije artikulirati.

Dakako da ukazivanje na neumjerenost kapitalizma samo po sebi nije loše, no važno je to činiti na razumljiv i povijesno upućen način. Iako problemu granica ekonomskog rasta bez sumnje pridodaje filozofsku dubinu, ideja "civilizacij[e] koju su ljudi proteklih tisućljeća razvijali” (Domazet, u ovom broju) ne pridonosi boljem razumijevanju prirode terena na kojem se odvija borba oko problema okoliša. O kakvom se terenu radi? O spornom terenu, obilježenom kontinuiranim naporima neoliberalnih sila da vlastiti marketinški program preobraze u zdrav razum i osiguraju implementaciju tržišnih rješenja ekoloških problema. To znači da situacija ne izgleda povoljno za dobronamjerne ali naivne pokušaje stvaranja politički nedefiniranog globalnog subjekta koji će djelovati u interesu čovječanstva u cjelini.

Za to postoji nekoliko razloga. Na ideološkoj razini, neoliberali i pobornici marketinških rješenja općenito ne mare za nejednakost. Za njih, nejednakost je, da parafraziram Gordona Gekka, ${ }^{10}$ dobra. Nejednakost funkcionira. Nejednakost rasvjetljuje, probija i pokazuje smisao evolucijskog duha. Isto opravdanje moglo bi se navesti i za druge oblike ekonomske i političke neumjerenosti, naravno uz izuzetak neumjerenih proračunskih deficita koje valja smanjiti svim raspoloživim sredstvima. Nadalje, neoliberalni akademici, javni komentatori te think-tank grupacije (tzv. trustovi mozgova; op.prev.) spremno se pozivaju i na znanstveni diskurs i na anti-intelektualizam kako bi opravdali vlastito poricanje klimatskih promjena i negodovali protiv koraka koje valja poduzeti da bi se spriječile najrazornije posljedice klimatske krize okoliša. Domazet ispravno ističe da su ekonomska demokracija, promjene u društvenoj raspodjeli dohodaka i "kultur[i] koja civilizacijska postignuća povezuje s potrošačkim ponašanjem” ( $\mathrm{u}$ ovom broju), nužni sastojci za održivi razvoj u dvadeset prvom stoljeću. Međutim, shvaćeni kao cjelina ti su elementi nespojivi s kulturom poduzetništva i institucionalnim okvirom koji se razvija i na globalnoj i na lokalnoj razini. Dovoljno je prisjetiti se da je posljednji deset godina doslovce potraćeno na gomilu smiješnih pokušaja realizacije raznih shema trgovanja ugljikom, poput Europskog sustava trgovanja emisijama (EU ETS), koje ne samo da nisu uspjele smanjiti emisiju stakleničkih plinova, već su poslužile kao sredstvo subvencioniranja zagađivača koji ostvaruju neočekivane profite za energetske tvrtke diljem Europske unije (Hoffman 2011). Isti poduzetnički misterij nalazimo na europskoj poluperiferiji gdje se zajednička poduzetnička djelatnost uzdiže na razinu prijeko potrebne

\footnotetext{
${ }^{10}$ Lik u filmu Olivera Stonea Wall Street iz 1987.
} 
društvene hermeneutike, i to u tolikoj mjeri da se bilo kakva javna specifikacija kapitalističkog razvojnog pokreta kao pokretačke sile u sadašnjem slomu okoliša smatra riskantnom i nepromišljenom. Kritika kapitalističkog razvoja prihvatljiva je u specijaliziranim časopisima, dok se program djelovanja u stvarnom svijetu, kako se čini, vrti oko iznalaženja načina da se takozvanu poslovnu zajednicu potakne da odustane od sudjelovanja u daljnjem uništavanju našeg ekosustava.

U ovom trenutku nije važno jesu li su materijalni interesi poslovne zajednice ti koji pokreću dominantan ideološki okvir ili obratno. U trenutku kada se "nova vrsta organizacije znanja koja će omogućiti tumačenje složenosti različitih omjera pokretača sloma” (Domazet, u ovom broju) prevede u skladu s novom planetarnom vulgatom (Bourdieu i Wacquant 2001), poziv na intelektualnu mobilizaciju svest će se na neobavezni šapat. Novi vokabular poslodavaca, visokopozicioniranih državnih službenika i dužnosnika u nevladinim organizacijama, prepun pomodnih riječi kao što su fleksibilnost, upravljanje, zapošljivost, fragmentacija, isključivanje, nova ekonomija, zeleni rast, predstavlja, kako ističu Bourdieu i Wacquant, glavno oruđe dvaju društvenih aktera koji igraju istaknutu ulogu u tržišnom "ublažavanju” krize okoliša:

Jedan je stručnjak koji, u sjenovitim hodnicima ministarstava ili sjedišta kompanija, ili u izolaciji think-tank grupacija, priprema izrazito tehničku dokumentaciju, po mogućnosti zaodjenutu u jezik ekonomije ili matematike, kojoj je cilj opravdati političke izbore temeljene na izrazito ne-tehničkim razlozima ... drugi je carski savjetnik za komunikaciju - prebjeg iz akademskog svijeta koji je stupio u službu dominantnih, a čija je misija unijeti dašak akademskog u političke projekte novog državnog i poslovnog plemstva. (Bourdieu i Wacquant 2001: 5)

Te se grupe bave proizvodnjom znanja, no u pravilu nisu dovoljno znatiželjne da ispitaju na koji način "i pojedinačno iskustvo i veliki povijesni narativi tvore važnu smislenu cjelinu” koja pridonosi boljem razumijevanju "naše zajedničke budućnosti” (Domazet, u ovom broju). Ono što ih zanima jest prikazivanje kapitalizma kao složenog evolucijskog sustava koji najbolje funkcionira ako ga se ostavi na miru. Nadalje, osobito su dobro osposobljene za navođenje razloga zašto je demokracija opasna ako podrazumijeva prenošenje funkcije donošenja odluka na neuke mase. Stoga bi trebalo obratiti pozornost na sadržaj i način na koji sraz tržišta i prirode u novoj planetarnoj vulgati isključuje demokraciju i kolektivno djelovanje iz rasprave o društvenim i ekonomskim aspektima krize okoliša.

Ako je, kako sugerira Domazet, nužno definirati "globalni subjekt (mi)", to mora biti subjekt (mi) kojem nije dojadilo poštovati političku obvezu prema ljevici i koji ne zazire od postavljanja teških pitanja, poput onih koje u svojoj kritici ljevičarske melankolije postavlja Wendy Brown (1999):

Kakvu bismo to političku nadu mogli gajiti a da nije pogrešno utemeljena na ideji da je "povijest na našoj strani" ili da je pristajanje javnosti uz bilo koje vrijednosti koje bismo mogli razviti kao vrijednosti nove ljevičarske vizije neizbježno? Kakvu vrstu političkog i ekonomskog poretka možemo zamisliti, a da nije ni pod državnom upravom ni utopijski, ni represivan ni libertarijanski, ni ekonomski osiromašen ni zaodjenut u kulturno sivilo? (Brown 1999: 27)

Ako želimo otići korak dalje od pukog ukazivanja na očitu neumjerenost kapitalističke proizvodnje, tada moramo uzeti u obzir pitanja poput ovih. Pri suočavanju sa sadašnjim vlastima, identifikacija slabijih ili proturječnih točaka neoliberalnog programa trebala bi biti usko povezana s razvojem emancipatorskog protunarativa koji će ljevici omogućiti da izbjegne zamke koje postavljaju akademska zajednica i neoliberalne think-tank grupacije. 


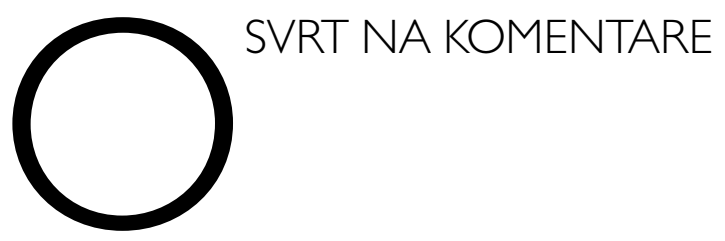

\section{Mladen Domazet}

Zahvalan sam Danijeli Dolenec, Vladimiru Cvijanoviću, Tomislavu Tomaševiću, Jeremyju Waltonu, Karin Doolan i Mislavu Žitku na kritičkim reakcijama na početni prijedlog i kontinuiranoj raspravi koja je oduvijek bila u središtu razmišljanja o održivosti kakvo utjelovljuje Grupa 22. Ova rasprava ukorijenjena je u pozadinskoj refleksiji transformativnog djelovanja koje svatko od njih poduzima unutar naše zajednice i vrstan je primjer razvoja promišljanja o održivosti kako je tumače i iznova osmišljavaju periferna društva Europe. To je prva stvar koja od diskusije koju ovdje vodimo poradi čitatelja ovog časopisa, čini nešto više od pukih slova raspoređenih u akademsko promišljanje o životu, posloženo oko pretvorbi energije, društvenih struktura koje ih koriste i upravljačkih mehanizama koji ih nadziru. Drugo nadtekstualno prisustvo u ovoj raspravi jesu ilustracije različitih diskursa, narativa, perspektiva i, što je najvažnije, zdravorazumskih svjetonazora o tome što bi refleksivno čovječanstvo trebalo naučiti iz vlastite povijesti i sadašnje situacije. To uključuje i stalni podsjetnik na to da treba nastaviti propitkivati njegovo tumačenje stvarnosti dok ga se istovremeno koristi za modifikaciju te iste stvarnosti. Upravo je potonji aspekt ove rasprave ono čemu se u ovom osvrtu najviše želim posvetiti.

Iznesene odgovore i komentare ne vidim kao spor u kojem će "pobijediti” najuporniji, te mogu smjesta i u potpunosti pristati na proširivanje uvodnog teksta prilozima mojih kolega; vjerujem da tu želju potvrđuju i mnogi uvodni pasusi samih tekstova. Unatoč tome, tekstovi iznose i ispravke, dodatke i prijedloge logičnih strategija koje valja detaljnije ispitati, te zahtijevaju pojašnjenja i nove definicije konceptualnih alata korištenih pri rješavanju problema. Neki od tekstova kombiniraju više spomenutih aspekata. Zahtjevi za ponovnim definiranjem konceptualnih alata možda su najznačajniji izazov upućen prijedlozima koje sam iznio u uvodnom članku. Oni također ilustriraju najvažniju razdjelnicu među istraživačima-aktivistima, sudionicima programa koji izvodi Grupa 22, a možda i zelena ljevica općenito. To je ujedno i najveći intelektualni izazov za filozofe, nenaviknute na to da njihovi intelektualni pothvati nalaze praktičnu primjenu. Stoga sam, unatoč vlastitom pozivu na povijesnu hitnost, i sam u napasti da razmotrim Waltonov poziv na "[intelektualnu] frikciju” kao mogućnost djelovanja i kontinuirane rasprave; ipak, komentari ovdje iznesenih komentara morat će ostati u naznakama, kao indikatori budućeg razmišljanja.

No za početak, ponovo malo povijesti. Zazivanje (povijesno ili geofizički) neizbježnog sloma civilizacije nesumnjivo ima maltuzijanski prizvuk. Povijesni Malthus - "apostol bogatih" (Shelley) i grešnik "protiv znanosti” (Marx) (usp. Shapin 2014) - obilno je klevetana figura koju obožavaju kao proroka i grde kao kvaritelja veselja razvojnog pokreta. Koji god stav zauzeli prema toj povijesnoj figuri (slobodno birajte među akademskim komentarima svaki put kad razvojna kriza postane dovoljno očita), Malthusovo naslijeđe korisna je ilustracija stranputica naše rasprave u prethodnim tekstovima. Neka od znanstvenih upozorenja o potencijalnom slomu civilizacije imaju eksplicitno maltuzijanske temelje: Ehrlich je, primjerice, predviđao maltuzijanski slom sustava prehrane sedamdesetih godina prošloga stoljeća, a debate o tome je li oskudnost pokazatelj konačnog iscrpljivanja margina ili poticaj za čudo- 
tvorno ponovno osmišljavanje čovječanstva (ili samo kapitalizma, usp. tekstovi Tomaševića, Doolan i Žitka u ovom broju) nastavljaju se i u dvadeset prvom stoljeću (Mayhew 2014). No ovdje je važan drugačiji pogled na povijesnu ostavštinu Malthusa, onaj koji se tiče izbora metodologije za analizu razvojnog projekta koji nazivamo civilizacijom.

Opis interakcije čovjeka i prirode koji nudi sam Malthus primjer je mehanističke znanosti, konstruktivno objašnjenje ${ }^{11}$ procesa "društvenog metabolizma" koji se, prema njegovom mišljenju, sastoji od elementarnih koncepata hrane, organizama i fundamentalnih zakona koji upravljaju njihovom vremenskom evolucijom: organizmi trebaju hranu kako bi preživjeli, a streme razmnožavanju. Pritom je hrana ograničeni resurs, a nagon za razmnožavanjem inherentno nezadovoljiv, što dovodi do geometrijske progresije u veličini populacije te (u konačnici) do oskudice hrane. U ovom nas kontekstu ne zanima je li tako postavljena ontologija točna ili ne: ono što nas zanima jest metoda anticipiranja i mogućeg racionalnog utjecanja na budućnost. Ovisno o mehanizmu, naše djelovanje usmjereno na budućnost sastoji se od izdvajanja i "prtljanja” po sastavnicama njegova djelovanja ne bi li izmijenili njegova konačna stanja. Osmišljavajući strategiju djelovanja konceptualno započinjemo s određenim hipotetskim elementima, elementarnim entitetima uz pomoć kojih konstruiramo mentalne modele složenih fenomena za koje očekujemo da ćemo ih promatrati ili izbjegavati. Za moju vlastitu analizu razvojnog projekta u smislu mehanizama pretvorbe energije, društvenih struktura koje ih koriste i upravljačkih mehanizama koji ih nadziru (u uvodnom tekstu) moglo bi se reći da slijedi taj pristup. U tom se otkrivam kao nepopravljivi fizičar koji slijedi Einsteinovu tvrdnju da razumjeti proces u konačnici znači pronaći konstruktivnu teoriju ${ }^{12}$ koja obuhvaća problematični proces (Einstein 1954).

Komentare Dolenec, Cvijanovića i Tomaševića - među ostalim njihovim pronicljivim konceptima, teorijama i strategijama kojima pridonose raspravi - razumijem kao dio sličnog svjetonazora. Oni uzimaju predložen ili sličan mehanizam i pitaju na koju se od njegovih komponenata može najučinkovitije utjecati da bi se buduće stanje kolapsa čitavog kompleksa modificiralo/izbjeglo. U tom smislu predstavljaju dio kritičkog mišljenja na ljevici, te glasno zagovaranog stava i unutar Grupe 22; ne zamaraju se sitnicama oko toga što bi narav čekića i srpa trebala biti, već što se, s obzirom na "hitnost zadatka koji je pred nama" (Dolenec, u ovom broju), sa svakim od njih sada može učiniti. Dolenec izrijekom zagovara davanje "skromni[h] praktični[h] prijedlo[ga]", dok istovremeno na umu imamo zadatak "divovskih razmjera” koji nas čeka. Prepoznajući inherentnu vezu između kapitalizma i rasta, te rasta i nejednakosti, čiju bi, pak, inherentnu povezanost s neodrživošću u postojećem razvojnom modelu i budućem slomu trebalo raskinuti, ona predlaže strategiju od-rasta čiji prvi korak leži u ponovnoj procjeni onoga što zapravo mjerimo kao napredak i civilizaciju. To je način da s vremenom postignemo promjene u pretvaranju energije potrebne za ublažavanje katastrofalnih klimatskih promjena pomoću sitnih zahvata u društvene strukture i upravljačke mehanizme, i to u one elemente koje svatko može lako razumjeti: blagostanje i dobrobit.

U jezgrovitom prikazu jedne transformativne (i potencijalno transdisciplinarne) škole ekonomskog mišljenja, Vladimir Cvijanović poziv na od-rast odvodi korak dalje, objašnjavajući da njegova primjena iziskuje nešto više od pukog obrtanja rasta štetnog BDP-a pod svaku cijenu. Sličnosti i paralele s njegovim prepoznavanjem hitnosti usmjeravanja detaljnih objašnjenja djelovanja povijesno stabilnih socio-ekonomskih konstelacija koje nudi pristup régulation na nevolje dvadeset prvog stoljeća, nalazimo u Žitkovom pozivu na imenovanje

\footnotetext{
${ }^{11}$ Konstruktivnim i principnim objašnjenjima u prirodnim znanostima, popularnoj paradigmi metode, detaljno sam se bavio u Domazet (2012).

${ }^{12}$ Nasuprot koje stoji jednostavnija, katkad i revolucionarna principna teorija (metoda) koju ćemo predstaviti u nastavku teksta.
} 
političkih aktera odgovornih za status quo i Waltonovoj tvrdnji da istraživanje društvene dinamike mora ubrzati primjenu objasnidbenog modela koji nastaje kao njen rezultat. No Cvijanović (s kojim se mogu tek skromno složiti) tvrdi "da se institucionalne inovacije za novu ekonomiju ne bi smjele sastojati od jednostavnih 'popravaka' postojećeg ekonomskog sustava”, zahtijevajući konačne značajne promjene u društvenim strukturama i upravljačkim mehanizmima koji graniče s postojećom tehnologijom pretvorbe energije. Prepoznavanje mehanizma koji djeluju pomoću vlastitih komponenata krajnji je cilj temeljne reorganizacije.

Kako bi značajne promjene mogle izgledati u praksi odlično je objašnjeno u Tomašićevom tekstu, koji predstavlja reifikaciju sva tri osnovna elementa civilizacije u modernom gradu te povijesnu ulogu suvremenih gradova u odnosu na kulturu i potrošnju resursa. Tehničko poimanje učinkovitosti resursa i ekonomije razmjera ovdje je dobro ilustrirano složenim fenomenom kojeg stvaraju ljudske populacije, težnje pojedinaca i strukture društvene reprodukcije. Nisam mogao zamisliti bolju ilustraciju za usvajanje pozicije budućeg sloma i posljedičnog bavljenja mišlju o (pretpostavljenim) prošlim protučinjeničnim mogućnostima, koje sam u uvodnom tekstu opisao kao "razmišljanje za dvadeset drugo stoljeće”. A ipak, baš kao i moj prijedlog, i te bi se ilustracije mogle percipirati kao utemeljene na konstruktivnoj metafizici buduće promjene. $U$ tom bi se smislu metodološki mogle povezati s poimanjem ekološke ekonomije i njenom materijalističkom ontologijom energetske vrijednosti i "prirode" kao ontološke osnove vrijednosti koja se definira kao "uživanje u životu” (Burkett 2006), te Malthusovim esencijalizmom interakcije između čovječanstva i prirode kroz determinističku evoluciju. Ovdje nas ne zanima je ti to točno ili pogrešno; zanima nas glasna kritika koju na račun oba stajališta upućuje marksistička analiza struktura kapitalističkog pripisivanja vrijednosti, kao temelj za drugačije reakcije na promišljanje o prošlim protučinjeničnim mogućnostima iz pozicije dvadeset drugog stoljeća.

Ako još uvijek čitate, stigli ste do trenutka u kojem se naš povijesni primjer ostvaruje. Malthusova mehanistička evolucija rastuće populacije u situaciju "u kojoj broj ljudi nadmašuje sredstva njihova izdržavanja” (usp. Shapin 2014) privukla je snažno protivljenje od strane marksističkih mislioca i kao znanstveno pogrešna i kao pretjerano pesimistična po pitanju transformativnog potencijala čovjeka. Na sličan način, Burkettova analiza kritizira ekološku ekonomiju iz marksističke (i stoga u biti radikalno kritične prema kapitalizmu) perspektive zbog pripisivanja pretjeranog ontološkog značaja kapitalističkim obrascima vrednovanja (Burkett 2006). Ono što je problematično iz perspektive marksističke ljevice ${ }^{13}$ nisu namjere ekološke ekonomije, već sama njena objasnidbena ontologija. Možda je ono što trebamo, mogli bi poručiti s marksističke ljevice, sasvim drugačiji objasnidbeni pristup, koji se ne temelji na postavljanju hipoteza o tome koji mehanizmi leže u pozadini kompleksa prirode i civilizacije, već na jednostavnim načelima koja nude generalizacije bez iznimaka o poželjnim budućim ishodima: umjesto protučinjenične igre u stilu što-bi-bilo-da-je-bilo, sastavljanje popisa potrebnih uvjeta ili ograničenja događaja koji na jednostavan i bjelodan način objašnjavaju kakav bi svijet morao biti da ne bi došlo do neželjenih ishoda; umjesto konstruktivne ontologije mogućih načina izbjegavanja sloma, objasnidbena generalizacija načela koja ograničavaju i definiraju željeni svijet bez kolapsa i s mogućnošću održavanja civilizacije. To je vatreno "trenje" koje ima potencijala da potakne stvaranje "glas[a] koji dopire iz [disciplinarne] perspektive opkoračenja” (Domazet, u ovom broju).

Iako priznajem da se teško može reći da je maltuzijanski pesimizam povijesno empirijski opovrgnut, to jest da još uvijek predstavlja primjenjivu metodu i ontološki okvir (izuzevši

\footnotetext{
${ }^{13}$ Isto ne vrijedi i za marksističku kritiku Malthusa, kojega se ismijava kao bezobzirnog reakcionara koji zagovara "ekskluzivne interese postojećih klasa ili njihovih segmenata" (Karl Marx. Theories of Surplus Value 2: 136-137).
} 
klasnu i "rasnu" neosjetljivost), uzimam za slobodu da preostala tri odgovora čitam u duhu kritike takve metode objašnjenja i predviđanja. U tom smislu, spomenuti odgovori nude jake argumente, pozivaju se na utjecajne povijesne preteče te čitatelju nude dobre ilustracije dubine rasprave uzduž političkog spektra između zelenih i ljevice. Jeremy Walton upozorava na opasnosti percepcije "klimatskih promjena kao niza 'kulturnih' utjecaja na 'prirodu”, nalik ontološkom razdvajanju tehnologija pretvorbe energije (koje uključuju i korištenje živih organizama) od društvenih struktura njihove uporabe. Usprkos tomu, Walton je svjestan opasnosti nemoćnog kolebanja između "simplicističk[og] [ontološkog] esencijaliz[ma]" i njegove potpune metodološke negacije, "karikiran $[\mathrm{og}]$ postmodernističk[og] relativiz[ma]" (Walton, u ovom broju). Njegov poziv na fokusiranje našeg kritičkog promišljanja na "propitkivanj[e] neoliberalnog kapitalizma” stoga uzimam kao primjer paradigmatskog metodološkog zaokreta od entiteta prema principima, "otpor učincima neoliberalnog kapitalizma” koji je "mnogolik i izmješten iz središta" kao okvir za ponovnu globalnu političku orijentaciju u dvadeset prvom stoljeću, umjesto inzistiranja na modifikacijama pojedinih intelektualno postavljenih povijesnih mehanizama.

Na sličan način, poziv Karin Doolan na upotpunjavanje racionalnih analiza prijetnji klimatskih promjena "emocionaln[im] reakcij[ama] na zabrinjavajuće ekološke probleme" (Doolan, u ovom broju) također bi se mogao shvatiti kao poziv na razumijevanje promjena koje trebamo u dvadeset prvom stoljeću kao paradigmatsko omeđivanje prostora djelovanja urođenim ljudskim afektivnim reakcijama na "katastrofe u neposrednoj blizini" (ibid.). Doolan traži da se političko-ekonomski kontekst i kulturno neprijateljstvo prema znanosti prepoznaju ne kao predmet akademskog istraživanja, već kao izravne prepreke djelovanju protiv klimatskih promjena i s njima povezanog sloma civilizacije. Znamo koji nam je oblik tranzicije potreban, intelektualna analiza trebala bi nam ponuditi alate potrebne za njegovu realizaciju, a ne uspostaviti istančaniju razinu opisnih detalja. Najodlučnije slaganje s analizom problema, ali iz potpuno drugačije paradigme, nalazimo u tekstu Mislava Žitka koji oštro kritizira povijesno neupućeno nabrajanje "neumjerenost[i] kapitalizma", zahtijevajući sasvim drugačiji "teren [... na kojem se odvija borba oko problema okoliša”. Ako želimo razumjeti promjenu potrebnu dvadeset prvom stoljeću o kojoj govorim u uvodnom tekstu, piše Žitko, tada u njoj moramo vidjeti borbu protiv “neoliberalnih sila”,a ne intelektualnu potragu za "politički nedefiniran[im]”, ravnodušnim razvojnim mehanizmom. Imenujmo protivnike koje treba svladati ("sadašnj[e] vlasti [...]"), navedimo koju "vrstu političkog i ekonomskog poretka” želimo vidjeti u dvadeset drugom stoljeću i počnimo ga uspostavljati što je prije moguće. Time Žitkov komentar zaključuje pregled diskusije i zabilježenog diskurzivnog zdanja tekuće rasprave za crveno-zelenu političku ekonomiju pod pritiskom sveobuhvatnog, materijalnog i mjerljivog sloma civilizacije.

Duboko sam zahvalan svim komentatorima i, uz isprike za nenamjerno pogrešno uokvirivanje njihovih stajališta u množini vrijednih analiza i strategija posvećenih problemu granica rasta u dvadeset prvom stoljeću, želio bih naglasiti da u znanosti i objašnjavanju općenito, razlike u objasnidbenim paradigmama nisu ni paralizirajuće ni uzaludne. Kao što povijesni primjer maltuzijanstva pokazuje, do potpunog kolapsa britanske populacije nije došlo 1825 . godine, kao ni do kolapsa svjetske populacije 2000. godine. No maltuzijanska zabrinutost zbog rasta danas podjednako dolazi do izražaja i u klimatskim prijetnjama i matematičkim modelima nosivog kapaciteta, dok razvojni projekt uzrokuje brojne mini-slomove i dovodi do toga da se nekima bolno uskraćuju oskudni resursi i da se eksternalije krijumčare gdje god je to moguće. Filozofski protuodgovor iz pozicije objasnidbenog procesa ontološkog opkoračenja bitno različitih razina mogao bi istaknuti da temeljna jedinica realističke ontologije nije 
trenutačno stanje hipotetičke strukture, već opća stvar. Stvari, koje prepoznajemo kao invarijantne, neizbrisivi su temelji iskustva, a naše poimanje transformacija koje vode ka održivosti moglo bi se temeljiti na onome što moramo održati kako bi mogli objasniti civilizirano, a živuće, čovječanstvo kao zajednički nazivnik različitih političkih strategija.

Ukratko, proučavanje onoga što razumijemo pod pojmovima napretka, civilizacije, reprodukcije i kapitalizma nije niti akademsko vježbanje "ljevičarske melankolije”, niti iznošenje politički praznih riječi upućenih utvrđenim strukturama moći (Žitko, u ovom broju). To je nužan civilizacijski, kulturni preduvjet za suradničko, smisleno djelovanje, partitura koja je podjednako važna za melodiju kao i napeta struna i čisti rog. To je objašnjenje koje tumači pustolovine koje dolaze, brzinom Grifonove opomene Alici da preskoči objašnjenja (koja "strašno dugo traju") i samo opiše niz događaja (Lewis Carroll, Alica u Zemlji čudesa). Na koncu, Grifon je nagao, prezriv i bahat lik koji ne završi dobro. Unatoč, ovdje uglavnom nepobijenoj, afektivnoj hitnosti sadašnjeg geofizičkog i povijesnog položaja čovječanstva, postizanje suglasnosti oko zajedničkog nazivnika političke borbe kojoj je cilj "promijeniti svijet klimatskih promjena” (Walton, u ovom broju) prvi je korak u odabiru racionalnih $\mathrm{i}$ iracionalnih strategija kojima se s njome hvatamo u koštac (obje su nepromjenjiva obilježja čovječanstva, de Sousa 2004). Čitajte, odlučite sami, organizirajte se, surađujte, pridružite nam se. 